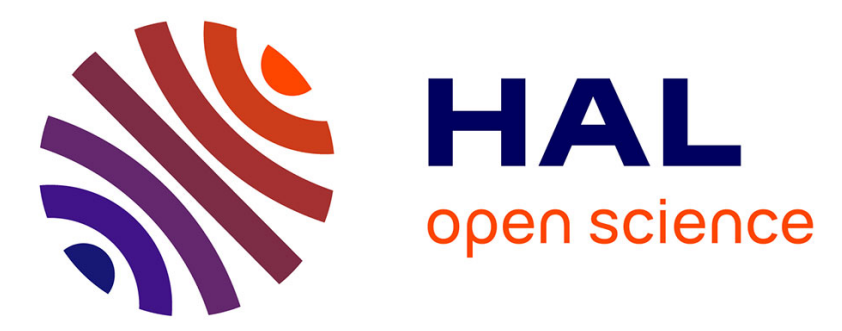

\title{
Diachronic metamorphic and structural evolution of the Connecticut Valley-Gaspé trough, Northern Appalachians
}

Morgann Perrot, Alain Tremblay, Gilles Ruffet, Loic Labrousse, Félix Gervais, Fabien Caroir

\section{To cite this version:}

Morgann Perrot, Alain Tremblay, Gilles Ruffet, Loic Labrousse, Félix Gervais, et al.. Diachronic metamorphic and structural evolution of the Connecticut Valley-Gaspé trough, Northern Appalachians. Journal of Metamorphic Geology, 2020, 38 (1), pp.3-27. 10.1111/JMG.12510 . insu-02295362

\section{HAL Id: insu-02295362 \\ https://hal-insu.archives-ouvertes.fr/insu-02295362}

Submitted on 24 Sep 2019

HAL is a multi-disciplinary open access archive for the deposit and dissemination of scientific research documents, whether they are published or not. The documents may come from teaching and research institutions in France or abroad, or from public or private research centers.
L'archive ouverte pluridisciplinaire HAL, est destinée au dépôt et à la diffusion de documents scientifiques de niveau recherche, publiés ou non, émanant des établissements d'enseignement et de recherche français ou étrangers, des laboratoires publics ou privés. 
DR. MORGANN GWENVA PERROT (Orcid ID : 0000-0002-9699-9247)

Article type : Original Article

\section{Diachronic metamorphic and structural evolution of the Connecticut Valley-Gaspé trough, Northern Appalachians.}

\section{Morgann Perrot ${ }^{1}$; Alain Tremblay¹; Gilles Ruffet ${ }^{2}$; Loic Labrousse ${ }^{3}$; Félix Gervais ${ }^{4}$; Fabien} Caroir $^{3}$

${ }^{1}$ Université du Quebec à Montréal-Geotop, Département des sciences de la Terre et de l'atmosphère, Case postale 8888, Succursale Centre-ville,

Montréal, Quebec, H3C 3P8, Canada, perrot.morgann@uqam.ca, tremblay.a@uqam.ca.

${ }^{2}$ CNRS (CNRS/INSU), Université de Rennes 1, Géosciences Rennes. 263 av. du général Leclerc, Rennes Cedex, 35042 France,gilles.ruffet@univ-rennes1.fr

${ }^{3}$ Institut des Sciences de la Terre de Paris, University of Paris 06-CNRS, UMR 7193, F-75005, Paris,France,loic.labrousse@upmc.fr,fabien_caroir@hotmail.com

${ }^{4}$ Département des Génies Civil, Géologique et des Mines, École Polytechnique de Montréal, C.P. 6079, succursale Centre-Ville, Montréal, Quebec H3C 3A7, Canada, felix.gervais@polymtl.ca

This article has been accepted for publication and undergone full peer review but has not been through the copyediting, typesetting, pagination and proofreading process, which may lead to differences between this version and the Version of Record. Please cite this article as doi: 10.1111/JMG.12510

This article is protected by copyright. All rights reserved 


\section{ABSTRACT}

The Connecticut Valley-Gaspé (CVG) trough represents a major, orogen-scale SilurianDevonian basin of the Northern Appalachians. From Gaspé Peninsula to southern New England, the CVG trough has experienced a contrasting metamorphic and structural evolution during the Acadian orogeny. Along its strike, the CVG trough is characterized by increasing strain and polyphase structures, and by variations in the intensity of regional metamorphism and contrasting abundance of 390 to $370 \mathrm{Ma}$ granitic intrusions. In southern Quebec and northern Vermont, a series of NW-SE transects across the CVG trough have been studied in order to better understand these along-strike variations. Detailed structural analyses, combined with phase equilibria modeling, Raman spectrometry and muscovite ${ }^{40} \mathrm{Ar} /{ }^{39} \mathrm{Ar}$ dating highlight a progressive and incremental deformation involving south-north variation in the timing of metamorphism. Deformation evolves from a $\mathrm{D}_{1}$ crustal thickening event which originates in Vermont and progresses to southern Québec where it peaked at $0.6 \mathrm{GPa} / 380^{\circ} \mathrm{C}$ at c. $375 \mathrm{Ma}$. This was followed by a $\mathrm{D}_{2}$ event associated with continuous burial in Vermont from $378 \mathrm{Ma}$ to $355 \mathrm{Ma}$, which produced peak metamorphic conditions of 0.85 $\mathrm{GPa} / 630^{\circ} \mathrm{C}$ and exhumation in Quebec from 368 to $360 \mathrm{Ma}$. The $\mathrm{D}_{3}$ compressional exhumation event also evolved from south to north from 345 to 335 Ma. $D_{1}$ to $D_{3}$ deformation events form part of a continuum with an along-strike propagation rate of $\sim 50 \mathrm{~km} / \mathrm{m}$.y. During $\mathrm{D}_{1}$, the burial depth varied by more than $15 \mathrm{~km}$ between southern Quebec and Vermont, and this can be attributed to the occurrence of a major crustal indenter, the Bronson Hill Arc massif, in the New England segment of the Acadian collision zone.

Key Words: Connecticut Valley-Gaspé trough, Gaspé Belt, Acadian orogeny, Northern Appalachians, P-T-t evolution, Differential burial and exhumation

This article is protected by copyright. All rights reserved 


\section{INTRODUCTION}

Increasing metamorphism linked to orogen building is generally perpendicular to the strike of orogens but occasionally along-strike variations can be observed, for example, in the Pyrenees (Vacherat et al., 2016) or in the Appalachians (Tremblay \& Pinet, 2016; Tremblay, Ruffet, \& Castonguay, 2000). The Connecticut Valley-Gaspé trough in the Northern Appalachians of northeastern North America is an excellent location to investigate the cause of such a less-common spatial expression of regional metamorphism because of its good exposure and extended metamorphic and structural analyses already done in several parts of the trough (e.g. Armstrong, Tracy, \& Hames, 1992; Roy, 2008; Spear, Kohn, Cheney, \& Florence, 2002; Tremblay et al., 2000, among others).

The Appalachian Belt was built during four main orogenic events, the Taconic (c. 470-450 Ma), Salinic (c. 440-425 Ma), Acadian (c. 390-360 Ma) and Alleghanian (c. $300 \mathrm{Ma}$ ) orogenies. The Acadian orogen, which corresponds to a plate collision between the composite Laurentian margin and the micro-continent Avalonia, contains many structural and metamorphic features that are still poorly understood. For example, there have been numerous debates in the literature regarding the asynchronous peak metamorphism and metamorphic conditions along the collision zone (Harrison, Spear, \& Heizler, 1989; Spear et al., 2002), the inferred impact of the initial geometry of the colliding plates, and the possible partitioning of crustal deformation between orthogonal and transpressional structures (e.g. Kuiper, 2016; Massey, Moecher, Walker, O'Brien, \& Rohrer, 2017; McWilliams, Kunk, Wintsch, \& Bish, 2013; Tremblay et al., 2000; Tucker, Osberg, \& Berry, 2001).

In the Northern Appalachians, the Connecticut-Valley-Gaspé (CVG) trough (Figure 1) hosts a major Silurian-Devonian sedimentary sequence that extends along a NE-SW strike for more than a thousand kilometers, from southern New England (USA) to Gaspé Peninsula (Canada). This sedimentary sequence was deposited following the Salinic orogeny during a transition from extension to foreland basin development, the latter being associated with the westward migration of the Acadian deformation (Bradley, Tucker, Lux, Harris, \& McGregor, 2000; Perrot, Tremblay, Ruffet, \& David, 2018). The CVG trough records an increase in metamorphic grade from very low grade in the Gaspé Peninsula (Roy, 2008) to amphibolite facies and higher in New England (Armstrong et al., 1992; Spear et al., 2002). Similarly, regional deformation evolves from a single phase of open folding and strike-slip faulting in Gaspé Peninsula (Bourque, Malo, \& Kirkwood, 2000; Bourque, Brisebois, \&

This article is protected by copyright. All rights reserved 
Malo, 1995; Malo, Tremblay, Kirkwood, \& Cousineau, 1995), to polyphased deformation with up-tofour events of folding and faulting in New England (Hatch \& Stanley, 1988; White \& Jahns, 1950; Wintsch, Kunk, Boyd, \& Aleinikoff, 2003). Along with these structural and metamorphic variations, more Silurian-Devonian granitic intrusions are present in New England compared to Quebec (Figure 1B). The southern Quebec and northern Vermont segments of the CVG trough, with a low- to medium-grade of regional metamorphism and no significant Alleghanian metamorphic overprint (compared to Massachussetts and southward in New England, see Wintsch et al., 2003) are considered as key regions to understand and compare along-strike Acadian structural and metamorphic variations.

The observed southward increase in metamorphic grade and structural complexity implies that rock units in the south have been exhumed from deeper crustal levels but several scenarios could explain such variations (in sedimentary sequences that were deposited synchronously). For example, increasing plutonic activity could be, either, the expression of higher thermal flux and/or deeper crustal level of erosion in the southern part of the CVG trough, whereas a more intense crustal deformation in central-southern New England relative to Vermont and Quebec could be attributed to asymmetric collision and a smaller initial distance between converging plates during the Acadian orogenic cycle. Linking the various deformation phases to burial/exhumation path of these rocks is therefore crucial to understand the cause of the different metamorphic evolutions that occurred along the strike of the basin. In this contribution, we present and discuss a series of structural, metamorphic and thermochronologic data from four transects along the CVG trough (Figure 1B). The St-George, La Patrie, Coaticook and St-Johnsbury transects. Our new data and analyses are used to characterize the style of deformation and to constrain the timing and duration of deformation/metamorphism in order to better understand the asynchronous compressional burial, exhumation and granitic plutonism during the Acadian orogeny.

\section{GEOLOGICAL SETTING}

The CVG trough, situated north of the New-York promontory and east of the Québec reentrant, contains Late Ordovician to Middle Devonian sedimentary sequences belonging to the Gaspé Belt in Quebec and to the Connecticut Valley Sequence in New England (Figure 1, see Perrot 
et al., 2018 for a stratigraphic synthesis). In the Quebec Appalachians, the western boundary of the CVG trough is marked by the Troisième-Lac and Shickshock-Sud faults in Gaspé Peninsula, and the La Guadeloupe fault in southern Quebec. The eastern boundary is less well-defined, especially in northern Maine and New Brunswick, where the Gaspé Belt merges eastward into the Central Maine basin (Figure 1, also known as the Merrimack trough, see Tremblay \& Pinet, 2005). In southern Quebec and New-England, the CVG trough is separated from the Central Maine Basin the Chain Lake massif (Gerbi, Johnson, \& Aleinikoff, 2006) and the Bronson Hill/Boundary Mountains anticlinorium (Moench, 1993; Moench \& Aleinikoff, 2003; Rankin, Tucker, \& Amelin, 2013; Tucker \& Robinson, 1990) by fault contacts (such as the Thrasher Peaks and Monroe faults). The stratigraphy, depositional age constraints, regional deformation, magmatism and metamorphism of the CGV are described in more detail below.

\subsection{Stratigraphy and Depositional Age Constraints}

The stratigraphic subdivisions of the CVG trough are best preserved in the Gaspé Peninsula where Acadian metamorphism is of very-low grade (Roy, 2008) and well-defined biostratigraphic constraints exist (see Bourque et al., 2000). In southern Quebec and New England, lithostratigraphic units of the CVG trough are thought to be correlative to the late Silurian and Devonian units of the Gaspé Peninsula (i.e. the Chaleurs Group; Bourque et al., 2000; Lavoie, 2004). Recent geological mapping and compilation of historical data (Rankin \& Tucker, 2009; Tremblay, De Souza, Perrot, \& Theriault, 2015), as well as detrital and magmatic zircon dating (McWilliams, Walsh, \& Wintsch, 2010; Perrot, 2018; Perrot et al., 2018) have lead to an updated stratigraphic subdivision of the CVG trough in southern Quebec and Vermont. At the base, conglomerate, limestone and siliciclastic rocks of the Lac Lambton Formation correlate with the Shaw Mountain and Northfield formations of Vermont. Eastward, these rocks grade into impure limestone, calcareous mudstone, slate/shale, sandstone and minor quartzite of the correlative Ayer's Cliff and Waits River formations. These units grade upward into the Compton and Gile Mountain formations that consist of interlayered quarzitic to feldspathic sandstone and mudslate. Eastward, the Compton/Gile Mountain formations are in fault contact with the early Silurian Frontenac Formation, which is mainly made up of quarzitic sandstone interlayered with $432 \pm 8$ Ma mafic volcanic rocks (Dorais, Marvinney, \& Markert, 2017).

This article is protected by copyright. All rights reserved 
In southern Quebec, Chitinozoan fauna and plant remnants suggest that the Ayer's Cliff and Compton formations were deposited during the Early Devonian (Asselin, 2002; Hueber, Bothner, Hatch, Finney, \& Aleinikoff, 1990; Lavoie \& Asselin, 2004). This age range is consistent with maximum depositional ages constrained by detrital zircon U-Pb dating (Perrot et al., 2018 and references therein), which yielded youngest age clusters of $413 \pm 7$ Ma for the upper part of the Compton Formation, $406 \pm 9$ Ma for the Waits River Formation and $401 \pm 6 \mathrm{Ma}$ for the Gile Mountain Formation.

\subsection{Regional Deformation, Magmatism and Metamorphism}

In Quebec and New England, the CVG trough records Middle Devonian Acadian deformation, metamorphism and magmatism. Shortening deformation in the Gaspé Belt and the Connecticut Valley sequence is expressed by the development of increasingly penetrative and polyphase structures toward the south, also regional metamorphism is of higher grade in New England (Armstrong et al., 1992; Tremblay et al., 2000). For simplicity and clarity, here we combine newly derived structural data from the current study with recent (figures and maps, Perrot, 2018; Perrot \& Tremblay, 2017) and historical data. The transition between single-phase structures typical of the southern Quebec transect (Figures 1 and 2A) and multi-phase structures typical of the St. Johnsbury transect in northern Vermont (Figures 1 and 2D) occurs around the La Patrie and Coaticok transects (Figure 1 and 2B).

\subsubsection{Deformation}

Between the St-Georges and La Patrie transects, the regional deformation $\left(D_{1}\right)$ is thought to be the principal and oldest deformational event related to the Acadian orogeny (Tremblay et al., 2000) and is expressed by the formation of a major regional syncline (see folded bedding in Figure 1). It is characterized by NW-verging, steeply-inclined and gently to moderately plunging $F_{1}$ folds (Figure $2 \mathrm{~A})$, which exhibit a well-developed, SE-dipping axial-planar schistosity $\left(\mathrm{S}_{1}\right)$ and are locally overturned and refolded (Figure 2B-D, Lafrance, 1995; Tremblay \& Pinet, 2016; Tremblay et al., 2000).

In the La Patrie transect (Figure $2 \mathrm{~B}), \mathrm{F}_{1}$ are tight to isoclinal folds slightly plunging $\left(10^{\circ}-25^{\circ}\right)$ towards the north (Figure 3 ). $\mathrm{S}_{1}$ trends $\mathrm{N}$ to $\mathrm{NE}$ and varies from moderately to steeply-dipping $\left(40^{\circ}\right.$ $75^{\circ}$ ) toward the NW (Figure 3B and 4). This NW-dipping orientation is likely due to the effect of $\mathrm{D}_{2}$ shortening. Southward, in the Coaticook transect (Figure 2C), $\mathrm{F}_{1}$ folds are progressively overprinted

This article is protected by copyright. All rights reserved 
by $\mathrm{F}_{2}$ folds that verge towards the SE and the NW in the western and eastern parts of the CVG trough, suggesting the existence of a large-scale $\mathrm{D}_{2}$ fold in this area (Figures $3 \mathrm{~B}$ and $\mathrm{D}$ ). $\mathrm{F}_{2}$ folds are associated with an axial-planar crenulation cleavage or schistosity $\left(\mathrm{S}_{2}\right)$ wrapping around the Averill pluton (Figures 3D and 4). Locally, these $\mathrm{D}_{2}$ structures are overprinted by a late-stage crenulation cleavage ( $\mathrm{S}_{3}$, Figures $3 \mathrm{C}$ and 4$)$ which seems to coincide, at least locally, with the occurrence of a front of polyphase folding $\left(\mathrm{F}_{1} / \mathrm{F}_{3}\right)$ possibly related to the Bella fault (Figure 1, Lafrance, 1995).

In Vermont, $\mathrm{S}_{1}$ (correlative of S1-2 schistosity of Hatch \& Stanley, 1988; White \& Jahns,

1950 ) is associated with an early generation of NW-verging, syn- $D_{1}$ recumbent folds. These recumbent folds are overprinted by SE-verging folds and a penetrative, axial-planar $\mathrm{S}_{2}$ crenulation cleavage (Walsh, Kim, Gale, \& King, 2010). $S_{1}$ and $S_{2}$ structures are overprinted by late-stage, northtrending $\mathrm{F}_{3}$ folds with a weakly-developed, although locally pervasive, crenulation cleavage, $\mathrm{S}_{3}$.

\subsubsection{Magmatism}

Middle Devonian granitic plutons intrude the Silurian-Devonian rocks of the CVG trough. Their abundance increases from southern Quebec to northern Vermont. No plutons north of the La Patrie transect have yielded concordant U-Pb ages (Bourne, 1984, 1986a, 1986b; Simonetti \& Doig, 1990), therefore the ${ }^{39} \mathrm{Ar} /{ }^{40} \mathrm{Ar}$ muscovite age of $373 \pm 2 \mathrm{Ma}$ from the Lake Aylmer pluton (Tremblay et al., 2000) is considered the best estimate for the timing of magmatism in this area. South of the Coaticook transect, the Averill pluton (Figure 1) yielded a U-Pb zircon age of $367.8 \pm 0.3 \mathrm{Ma}$ (Perrot et al., 2018). P-T conditions of pluton emplacement inferred from contact metamorphic assemblages of several of these plutons are 0.2 to $0.4 \mathrm{GPa}$ and $500-600^{\circ} \mathrm{C}$ (Bourne, 1984, 1986a, 1986b; Erdmer, 1981)

In Vermont, the Knox Mountain Pluton (Figure 1) yielded a monazite U-Th-total $\mathrm{Pb}$ crystallization age of $377 \pm 5 \mathrm{Ma}$ (Lagor, 2016), whereas the Barre granite (Figure 1) and the Guilford pluton yielded zircon U-Pb crystallization ages of $368 \pm 4$ Ma and $366 \pm 1$ Ma (Aleinikoff, Ratcliffe, \& Walsh, 2011), respectively. All of these plutons have been interpreted as late to post- $\mathrm{D}_{1}$, possibly coeval with $\mathrm{D}_{2}$ or $\mathrm{D}_{3}$ (late to post-D1-2; Hannula et al., 1999; Richter, 1987; Westerman \& Coish, 2009), and originating from a variety of crustal and/or mantle melting processes (Arth \& Ayuso, 1997). P-T conditions of pluton emplacement inferred from contact metamorphic assemblages of several intrusions are 0.3 to $0.55 \mathrm{GPa}$ and c. $575^{\circ} \mathrm{C}$ (Anderson \& Coish, 1999; Hannula et al., 1999),

This article is protected by copyright. All rights reserved 
suggesting an emplacement depth of 8-16 km (Westerman \& Coish, 2009), similar to the P-T estimates from southern Quebec.

\subsubsection{Timing of Metamorphism and Deformation}

In southern Québec, regional peak metamorphism $\left(\mathrm{M}_{1}\right)$ varies from prehnite-pumpellyite to greenschist facies in the St-George transect to the biotite zone in the Coaticook transect (Figures 5A to $C)$. The age of $\mathrm{D}_{1}-\mathrm{M}_{1}$ has been locally constrained by ${ }^{40} \mathrm{Ar}-{ }^{39} \mathrm{Ar}$ muscovite ages of $380-375 \mathrm{Ma}$ from greenschist-grade Ordovician volcanic and plutonic rocks (Tremblay et al., 2000). The metamorphic aureole of the c. $368 \mathrm{Ma}$ Averill pluton (Perrot et al., 2018) contains staurolite and biotite porphyroblasts wrapped by $\mathrm{S}_{2}$ and preserving evidence for post- $\mathrm{D}_{1}$ recrystallization and/or rotation (Figures 5B and C). When combined with the wrapping of $\mathrm{S}_{2}$ around the pluton (Figure 4), such features suggest a syn- to pre- $\mathrm{D}_{2}$ emplacement for the pluton and also suggest that $\mathrm{D}_{2}$ occurred at c. $368 \mathrm{Ma}$ or after.

In New England, the regional metamorphic grade in the Connecticut Valley sequence (CVS) varies from the garnet zone of the greenschist-facies to the kyanite zone of the amphibolite facies (Laird \& Albee, 1981; Osberg, 1989). In Connecticut, D1 was estimated to reach peak metamorphism conditions of $575-700^{\circ} \mathrm{C}$ and 0.6-1.0 GPa at c. $390 \mathrm{Ma}$ (Armstrong et al. (1992 and references therein). In southern Vermont, conventional thermobarometry constrained peak P-T conditions in the kyanite zone at c. $550^{\circ} \mathrm{C} / 0.8 \mathrm{GPa}$ (Ferry, 1994). The timing of $\mathrm{D}_{2}$ has been estimated by a Sm-Nd age of c. $378 \mathrm{Ma}$ from the rim of a $\mathrm{M}_{2}$ garnet porphyroblast (Vance \& Holland, 1993), however, this age was later interpreted as recording prograde metamorphism (Spear et al., 2002). Kyanite and staurolite porphyroblasts overgrow the penetrative $S_{1}$ (associated with recumbent $F_{1}$ ), also, the Ky-in isograd is folded by $\mathrm{F}_{3}$ folds (Figure 6), therefore the metamorphic peak, which reached the kyanite zone, is interpreted as post- $\mathrm{D}_{1}$, but pre- $\mathrm{D}_{3}$ (Wing, Ferry, \& Harrison, 2003 and references therein). Wing et al. (2003) demonstrated that the kyanite-in isograd coincided spatially with the monazite-in isograd, which has a ${ }^{208} \mathrm{~Pb} /{ }^{232} \mathrm{Th}$ age of $353 \pm 9 \mathrm{Ma}$. The latter metamorphic ages (Wing et al., 2003), combined with ${ }^{40} \mathrm{Ar} /{ }^{39} \mathrm{Ar}$ muscovite cooling ages of c. $355 \mathrm{Ma}$ (McWilliams et al., 2013), have been interpreted as related to peak metamorphism and thus record a maximum age for $\mathrm{D}_{3}$ in southern Vermont. The last folding stage, $\mathrm{D}_{3}$, is thought to represent a differential uplift exposing in the core of $\mathrm{D}_{3}$ domes the deepest part of the metamorphic sequence (as in the Chester Dome area, for instance,

This article is protected by copyright. All rights reserved 
see Spear et al., 2002), with estimated P-T conditions in the range of $0.8-1.1 \mathrm{GPa}$ and $500-650^{\circ} \mathrm{C}$ (Kohn \& Spear, 1990; Menard \& Spear, 1993). Isograds are also present around plutons in northern Vermont (Figure 6), notably, sillimanite-in and andalousite-in isograds (see Osberg, 1989; Spear et al., 2002).

\section{METAMORPHIC AND THERMOCHRONOLOGICAL RESULTS}

In order to quantify the southward increasing metamorphic gradient in the CVG trough and its possible links with the c. 390 to 370 Ma granitic intrusions in the central part of the trough, a series of NW-SE transects (see section 1) have been studied in southern Quebec and northern Vermont. We used Raman spectrometry on carbonaceous material (RSCM, Beyssac, Goffé, Chopin, \& Rouzaud, 2002) to determine the temperatures in greenschist and lower amphibolite facies rocks, while pressure estimates were calculated using phase equilibria modeling. Phase equilibria modelling was used to derive pressure-temperature conditions for amphibolite facies rocks. Muscovite and biotite single grain ${ }^{40} \mathrm{Ar} /{ }^{39} \mathrm{Ar}$ ages were combined with these P-T results. A detailed description of the methodology for each technique is given in Appendix S1 whereas sample locations, correlation between analyses number and field sample numbers are shown in Table S1.

\subsection{Pressure-temperature conditions}

\subsubsection{RSCM data.}

All RSCM temperatures and parameters are listed in Table S2 and are plotted on a regional map (Figure 7). Raman spectra of greenschist facies samples exhibit a band pattern similar to those observed for poorly ordered carbonaceous material (Aoya et al., 2010; Beyssac et al., 2002), which means that they could be decomposed following the fitting procedure proposed in Beyssac et al. (2002). The band-areas were used to calculate the R2 ratio of Raman parameters from Beyssac et al. (2002), which vary between 0.18 and 0.65 for our samples. 16 to 21 spectra per sample have been acquired (see Table S2) and a mean temperature has been calculated for each sample using the equation $\mathrm{T}\left({ }^{\circ} \mathrm{C}\right)=-445^{*} \mathrm{R} 2+641$ (Beyssac et al. 2002; Table S2). Carbonaceous samples, that contain very little disordered graphitic carbon, but perfectly ordered graphite are generally from the aureole of granitic plutons. We assigned to those samples a $\mathrm{T} \geq 600^{\circ} \mathrm{C}$, which is in the upper bound of the calibration proposed by Beyssac et al. (2002). 
Calculated temperatures range between $348^{\circ} \mathrm{C}$ and $560^{\circ} \mathrm{C}$, with uncertainties $<30^{\circ} \mathrm{C}$ (Table S2) and define a coherent spatial distribution. RSCM temperatures ranging between $350-370^{\circ} \mathrm{C}$ are found in the northern part of the study area, whereas higher temperatures, with values ranging between $498-560^{\circ} \mathrm{C}$, are observed in the southern part (Figure 7). Low RSCM temperatures were found toward the northernmost transect (i.e. St-Georges) of southern Quebec, where the metamorphism of the shales is very low grade, and highest RSCM temperatures were observed near the plutons in the Coaticook transect.

RSCM temperatures (Figure 7) define isotherms that are arcuate and concave toward the northeast, a geometry that is consistent with the occurrence of a regional syncline structure in the CVG trough. However, the pattern of these isotherms cuts across stratigraphic contacts, which suggests that they were defined during folding and shortening of the basin. At the Quebec-Vermont border, the $500^{\circ} \mathrm{C}$ isotherm is concave toward the south and seems to be superimposed on the 380 and $420^{\circ} \mathrm{C}$ isotherms, a geometry that is best explained by the late/post-metamorphic emplacement of the Averill pluton (Figure 7).

\subsubsection{Phase equilibria modeling.}

Five samples from the Compton/Gile Mountain formation have been collected for phase equilibria modelling to derive P-T paths and calculate peak metamorphic conditions. The following samples were chosen on the basis of their index mineral-assemblage and location in the basin (see Figure S1): one chlorite-mica-bearing sample from the Lac-Mégantic area (QC11), two biotitebearing samples from the La Patrie transect (QC23 and QC22) and two garnet-bearing samples from the St. Johnsbury transect (VT1 and VT2). Their chemical compositions are considered to be representative of rocks of the basin as their bulk rock compositions plot within the same field on an AFM ternary diagram (Figure S1). Isochemical phase diagram sections (IPDS) were calculated using Perple_X 6.5.1 (Connolly \& Petrini, 2002; Connolly, 2005), in the $\mathrm{TiO}_{2}-\mathrm{MnO}-\mathrm{Na}_{2} \mathrm{O}-\mathrm{CaO}-\mathrm{K}_{2} \mathrm{O}-\mathrm{FeO}-$ $\mathrm{MgO}-\mathrm{Al}_{2} \mathrm{O}_{3}-\mathrm{SiO}_{2}-\mathrm{H}_{2} \mathrm{O}$ system, with $\mathrm{SiO}_{2}$ and $\mathrm{H}_{2} \mathrm{O}$ considered as saturated components. Gibbs freeenergy minimizations were carried out using the thermodynamic database of Holland and Powell (1998, updated in 2002) and a set of solution models that have been demonstrated to be robust (see Appendix S1 for details). Representative electron microprobe mineral analyzes are given in Table S3. Only results for samples QC23 and VT1 are discussed here because samples QC11, QC22 and QC23 
from southern Quebec, and samples VT1 and VT2 of central Vermont yielded similar P-T results (see figures S2, S3 and S4).

\section{Textural relationships and mineral compositions.}

Sample QC23 is a low-grade, fine-grained quartz-mica-chlorite metawacke from the La Patrie transect. A well-developed $\mathrm{S}_{1}$ schistosity is visible and marked by elongated quartz grains and the alignment of muscovite (Figure 5A). Accessory minerals are titanite, monazite, rutile, apatite, zircon and opaque minerals (mostly pyrite). Rounded detrital grains of quartz are surrounded by white micas, which are generally chloritized, and by oxides and organic matter. Most importantly, quartz grains show evidence for dynamic recrystallization with undulose extinction and grain boundary bulging recrystallization textures (Figure 5A) implying a deformation temperature between 300 and $400^{\circ} \mathrm{C}$ (Law, 2014).

White mica is the major index mineral in sample QC23. Potassium-rich $(\mathrm{Na}=1.2 \mathrm{wt} \%)$ white mica is dominant in the matrix and it shows a narrow range of compositions. The mica can be separated into two groups based on its $\mathrm{Si}$ apfu, the first group has $\mathrm{Si}=3.11-3.12$ apfu and the second contains 3.24-3.25 apfu. Because the former group is clearly aligned with the schistosity, it is interpreted as neoblasts

Sample VT1 is a fine-grained biotite-garnet schist from the St. Johnsbury transect. The main mineral phases are quartz, white mica, biotite, chlorite and garnet in decreasing proportion. Quantitative calculation of mineral modes in one thin-section using the software ImageJ yielded 5\% of 1 to $5 \mathrm{~mm}$-wide garnet crystals almost devoid of inclusions and $25 \%$ of c. $1 \mathrm{~mm}$-wide biotite crystals. Accessory minerals are ilmenite, which is abundant and generally included in biotite (Figure 5D), apatite, zircon, and opaque minerals (mostly pyrite). Flattening and recrystallization of quartz grains and K-rich white micas define the dominant schistosity $\mathrm{S}_{\mathrm{n}}$, which is interpreted to correspond to $\mathrm{S}_{1}$. The schistosity is generally overgrown by randomly oriented biotite porphyroblasts $(0.5-6 \mathrm{~mm})$ but is locally sigmoidal within some porphyroblasts (Figure 5D). Another discrete fabric cut the main schistosity and is interpreted as $\mathrm{S}_{2}$. It wraps around the biotite porphyroblasts and is also oblique to the $S_{1}$ foliation within them (Figure 5D), suggesting a growth of the biotite during a transition between these schistosities, or almost synchronous with $\mathrm{S}_{2}$. The 1 to $5 \mathrm{~mm}$ garnet porphyroblasts show textural evidence of two crystallisation stages with large cores $\left(\mathrm{Gt}_{1}\right.$ on Figures $5 \mathrm{E}$ and $\left.\mathrm{F}\right)$ that 
generally contain aligned trains of inclusions (oblique to the host schistosity) and thin rims rich in fine-grained inclusions ( $\mathrm{Gt}_{2}$, Figures $5 \mathrm{E}$ and $\mathrm{F}$ ). Chlorite is sometimes observed between garnet cores and rims. Garnet rims share crystal faces with biotite porphyroblasts (Figure 5E) and are also slightly wrapped by the $\mathrm{S}_{2}$ schistosity (Figure $5 \mathrm{~F}$ ). These textural features suggest synchronous growth of biotite and garnet rims $\left(\mathrm{Gt}_{2}\right)$ during the waning stage of deformation, i.e. pre- to syn- $\mathrm{S}_{2}$.

Mineral composition in sample VT1 helps to constrain the P-T path followed by isopleth thermobarometry: K-rich white micas contain 3.098 to $3.194 \mathrm{apfu} \mathrm{Si}$ and up to $0.24 \mathrm{wt} \% \mathrm{Na}$. Chlorite in this sample has a narrow range of compositions with $\mathrm{Mg} \#$ around 0.53 . Biotite contains $\mathrm{TiO}_{2}$ variations of 1.48-1.76 (wt \%) and a narrow range of $\mathrm{Mg} \#$ values between 0.495-0.506. Plagioclase shows a uniform composition of 0.23-0.25 apfu Ca (see Table S3). Rim to rim compositional profiles were obtained for the three largest garnet grains in one thin section. All three grains show similar profiles with a bell shape for spessartine, a $U$ shape for almandine, a flat shape for pyrope and a flat shape with a decrease at the rim for grossular (Figure 8). This type of zoning is characteristic of prograde growth (Spear, 1993; Harris et al., 2004). The grain with the highest spessartine has a core composition of $\mathrm{X}_{\mathrm{Sps}}=0.32, \mathrm{X}_{\mathrm{Gr}}=0.09, \mathrm{X}_{\mathrm{Py}}=0.03, \mathrm{X}_{\mathrm{Alm}}=0.56$, whereas the range of compositions for rims are: $\mathrm{X}_{\mathrm{Sps}}=0.09-0.04, \mathrm{X}_{\mathrm{Gr}}=0.11-0.06, \mathrm{X}_{\mathrm{Py}}=0.05-0.06, \mathrm{X}_{\mathrm{Alm}}=0.74-0.83$.

\section{Isochemical phase diagram section}

An IPDS for sample QC23 has been calculated to constrain pressure conditions for the lowgrade part of the CGV trough (Figure 9). The observed paragenesis (Chl-Ab-Ms-Ttn-Rt-Qz) is predicted to be stable within a triangular P-T field centered at $\sim 360^{\circ} \mathrm{C}$ and $0.25 \mathrm{GPa}$ (dark grey on Figure 9). In the absence of other temperature constraints, peak temperature reached by this sample is derived by the RSCM temperatures of that same sample, $380 \pm 20^{\circ} \mathrm{C}$, which is consistent with the temperature estimated from the grain boundary bulging recrystallization textures of quartz. Silica isopleths for the mica group with the lowest $\mathrm{Si}$ content $(\mathrm{Si}=3.11-3.15)$, interpreted as neoblast, intersect this temperature range between 0.5 and $0.7 \mathrm{GPa}$ (Figure 9). Although it is possible that peak pressure was reached before peak temperature, it is likely that the white mica neoblasts grew close to peak temperature and we, therefore, suggest that peak metamorphic conditions reached by this sample were $0.6 \mathrm{GPa}$ at c. $380^{\circ} \mathrm{C}$ (Figure 9).

This article is protected by copyright. All rights reserved 
Volume and compositional isopleths of sample VT1 that are compatible with textural relationships constrain a likely $\mathrm{P}-\mathrm{T}$ path (Figure 10). The two end points of the path are constrained by: 1) compositional isopleths for the garnet grain with the highest spessartine content that intersect closely at $\sim 0.5 \mathrm{GPa}$ and $520^{\circ} \mathrm{C} ; 2$ ) compositional isopleths for rim compositions that intersect at $\sim 0.85$ $\mathrm{GPa}$ and $630^{\circ} \mathrm{C}$ (Figure 10). We interpret the later intersection as evidence for negligible fractionation effect (Evans, 2004) for the small volume ( $5 \%)$ of garnet in this sample. The path in between these points has to be compatible with the following textural relationships (see Figures $5 \mathrm{D}-\mathrm{F}$ ): 1) $\mathrm{Gt}_{1}$ grew before biotite because 2) $\mathrm{Gt}_{2}$ grew synchronously with biotite as indicated by shared crystal faces (Figure 5E); 3) there is phase of garnet breakdown associated with chlorite growth in between the growth of $\mathrm{Gt}_{1}$ and $\mathrm{Gt}_{2}$, as indicated by resorbed margins rimmed by chlorite (Figure 5E and F); 4) the large (1-2 mm) ilmenite inclusions in biotite implies pre- to syn-biotite growth. A path compatible with these relationships would first involve a burial phase of $\sim 0.2 \mathrm{GPa}$ that would lead to garnet growth without affecting the other mineral phases (Figure 10). Then cooling of $\sim 50^{\circ} \mathrm{C}$ would induce garnet breakdown synchronous with chlorite growth while breaking down most of the biotite that would have already grown (no evidence for this breakdown was observed). Then a typical "orogenic" burial and heating path to the peak metamorphic conditions of $\sim 0.85 \mathrm{GPa} / 630^{\circ} \mathrm{C}$ would induce continuous garnet growth combined with ilmenite growth $\left(\sim 480^{\circ} \mathrm{C}\right)$ prior to a main phase of biotite growth $\left(\sim 530^{\circ} \mathrm{C}\right)$. A similar burial-cooling path was reconstructed from the Bronson Hill Arc Massif to the east (Spear et al., 2002) and recent 1D thermomechanical modeling (Gatewood \& Stowell, 2017) suggests that such paths are characteristic of nappe overthrusting.

\section{2. ${ }^{40} \mathrm{AR} /{ }^{39} \mathrm{AR}$ THERMOCHRONOLOGY.}

Single-grain ${ }^{40} \mathrm{Ar} /{ }^{39} \mathrm{Ar}$ analyses of muscovite and biotite were performed on 11 samples with a CO2 laser probe coupled with a MAP215 mass spectrometer (Appendix S1). The analyzed single grains of mica were, however, frequently very thin and small, down to c. $250 \mu \mathrm{m}$, in which case it was not possible to obtain detailed age spectra. The analytical procedure used here is described in Ruffet, Féraud, and Amouric (1991); Ruffet, Féraud, Balèvre, and Kiénast (1995), and the specifics

for our measurements are given in Appendix S1. Analytical data, parameters used for calculations and references are available in Table S4. By convention, plateau ages were calculated if $70 \%$ or more of the ${ }^{39} \mathrm{Ar}_{\mathrm{K}}$ was released in at least three or more contiguous steps (Ruffet et al., 1995). Pseudo-plateau

This article is protected by copyright. All rights reserved 
ages are defined with less than $70 \%$ of the ${ }^{39} \mathrm{Ar}_{\mathrm{K}}$ released and sometimes with less than three contiguous steps (see Appendix S1 for more details).

The sample QC11, from the Lac-Mégantic area (Figure 1), was used to study the age of the lowest metamorphic grade, samples QC25, QC21 and QC24 from the La Patrie transect, samples QC49, QC36, QC41 and QC31 from the Coaticook transect and samples VT3, VT4 and VT5 from the St. Johnsbury transect (see location on Figure 1) were used to constrain the timing of higher metamorphic grades. Note that some samples from southern Québec also yielded detrital ${ }^{40} \mathrm{Ar} /{ }^{39} \mathrm{Ar}$ white mica ages that have been presented and discussed by Perrot et al. (2018).

\section{Southern Quebec.}

In the Lac-Megantic area (Figure 1), sample QC11 is from the Lac-Drolet member of the Compton Formation. The $\mathrm{S}_{1}$ fabric is the only visible schistosity, it is well-developed and marked notably by the alignment of white mica. Metamorphic white micas yielded coherent age spectra with four plateau ages in the range of $375.3 \pm 2.2 \mathrm{Ma}($ mica $\beta$ ) to $379.9 \pm 1.4 \mathrm{Ma}$ (mica $\alpha$ ), and a frequency peak from all the analyzed micas at c. $376 \mathrm{Ma}$ (Figure 11A). Most of analyzed micas show evidence of a disturbance in the low-temperature steps at c. $347 \mathrm{Ma}$, which could be the result of a younger Acadian overprint. Considering that this sample was collected from an outcrop where $\mathrm{S}_{1}$ is the only penetrative the age peak of c. $376 \mathrm{Ma}$ can be reasonably interpreted as recording neocrystallization or complete recrystallization of white micas during the $\mathrm{D}_{1}$ phase of the Acadian orogeny.

In the La Patrie transect, sample QC25 is from the Ayer's Cliff Formation and samples QC24 and QC21 are from the Milan and Lac-Drolet members of the Compton Formation, respectively. White micas age spectra from sample QC25 (Figure 11B) all contain plateau ages with a frequency peak at c. 368.1 Ma. Two schistosities, $\mathrm{S}_{1}$ and $\mathrm{S}_{2}$, were observed at the sampling site of sample QC25 and its surroundings. Considering that the $\mathrm{S}_{1}$ schistosity is interpreted to be c. 375-380 Ma, as indicated by sample QC11, white micas of c. 368 Ma from sample QC25 can be thus reasonably attributed to the younger $\mathrm{S}_{2}$ schistosity. As for sample QC11, white micas of sample QC24 (Figure 11C) yielded coherent age spectra giving plateau (mica grains $\alpha$ and $\delta$ ) and pseudo-plateau (grain $\beta$ ) ages with a frequency peak at c. $376 \mathrm{Ma} . \mathrm{S}_{1}$ is the most penetrative fabric in sample QC24, the plateau ages are therefore assigned to metamorphic neo- or recrystallization at c. $376 \mathrm{Ma}$ during $\mathrm{D}_{1}$. In sample

QC24 the age spectrum from mica $\beta$ shows evidence for a radiogenic component in the low 
temperature steps with a pseudo-plateau age at $335.6 \pm 3.6 \mathrm{Ma}$, an age range that is similar to the low temperature steps of samples QC41 and QC33 from the Coaticook transect (see below). We interpret these low temperature ages as Ar disturbance related to $\mathrm{D}_{3}$. Mica $\chi$ from sample QC24 gave a plateau age at 369.4 $\pm 1.9 \mathrm{Ma}$, which overlaps with the ages from sample QC25 and therefore all of these ages are also ascribed to $\mathrm{D}_{2}$. The coexistence of ages from $\mathrm{D}_{1^{-}}$and $\mathrm{D}_{2}$ within samples QC24 and QC25 suggests that the youngest muscovite grains were recrystallized below their isotopic closure temperature during the $\mathrm{D}_{2}$ event at c. 366-369 Ma. At the eastern extremity of the La Patrie transect, sample QC21 was collected in an area with an intense NE-SW foliation related to the Bella fault. The two white micas that were analyzed, $(\alpha$ and $\beta$ ) yielded consistent plateau ages with a frequency peak at c. $353.3 \mathrm{Ma}$ (Figure 11D), which we interpret as related to the Bella fault.

In the Coaticook transect, sample QC49 is from the Ayer's Cliff Formation, samples QC40 and QC41 are from the Compton Formation and sample QC33 is from the Lac-Drolet member near the Bella fault. Sample QC49 is from an outcrop where the regional schistosity $\mathrm{S}_{1}$ is strongly overprinted by a penetrative $S_{2}$ and a more discrete $S_{3}$ crenulation cleavage. Four white micas grains yielded plateau ages in the range of $358.2 \pm 1.0$ (mica $\varepsilon$ ) to $360.4 \pm 1.3 \mathrm{Ma}$ (mica $\beta$ ) with a frequency peak at c. $360 \mathrm{Ma}$ (Figure 12A) that are interpreted as neocrystallization during the development of the main schistosity $\mathrm{S}_{2}$. Two mica grain yielded saddle-shaped age spectra (micas $\delta$ and $\phi$ ), which we interpret as due to the mixing of two different radiogenic components after partial recrystallization (see Appendix S1, Alexandrov, Ruffet, \& Cheilletz, 2002; Castonguay, Ruffet, \& Tremblay, 2007; Cheilletz et al., 1999; Tartese, Ruffet, Poujol, Boulvais, \& Ireland, 2011), with a first components thought to be late Devonian (at c. $360 \mathrm{Ma}$ ) and a second one at, or after c. $348 \mathrm{Ma}$. The older mica ages from the saddle shaped spectra can be tentatively interpreted as (re)crystallization linked to $\mathrm{S}_{2}$ foliation and/or as cooling ages related to the emplacement of the Averill Pluton (367.8 $\pm 0.3 \mathrm{Ma}$, Perrot et al., 2018), whereas the younger component, could be the result of a thermal disturbance linked with the $\mathrm{S}_{3}$ crenulation cleavage. Samples QC40 and QC41 are from an area where the $\mathrm{S}_{2}$ foliation is well developed. The age spectra of sample QC40 is consistent with (re)crystallization linked to $\mathrm{S}_{2}$, since it produced two plateau ages at 360.6 $\pm 1.0 \mathrm{Ma}$ and $359.0 \pm 1.1 \mathrm{Ma}$ and a frequency peak at c. $360 \mathrm{Ma}$, identical to sample QC49. In contrast, the muscovite grain measured from sample QC41 yielded a plateau age of $338.1 \pm 1.7 \mathrm{Ma}$ (Figure 12B). This young age is similar to the two 
analyzed white micas from sample QC33, which both yielded plateau ages at c. 335 Ma (Figure 12C). This later sample yielded three schistosities, with $S_{3}$ interpreted as related to $D_{3}$ (see Fig. 4), these Mississippian ages, found in samples QC41 and QC33, are attributed to $\mathrm{D}_{3}$.

\section{Northern Vermont.}

Along the St. Johnsbury transect (Figure 1), samples VT3 and VT4 were collected in the Waits River Formation whereas sample VT6 was collected from the Gile Mountain Formation. Samples VT3 and VT4 yielded similar ${ }^{40} \mathrm{Ar} /{ }^{39} \mathrm{Ar}$ age spectra (Figure 13A and B). Muscovite grain $\alpha$ from sample VT3 and muscovite grains $\alpha$ and $\beta$ from sample VT4 all produced saddle shaped age spectra with comparable characteristics. Their spectra likely express the mixing of two different radiogenic components, a former component with an apparent age at c. 344-345 Ma, which was subsequently disturbed by a younger event at, or after c. 336-338 Ma. For both samples, the validity of the age of the disturbance is reinforced by a pseudo-plateau age at $338.3 \pm 1.1$ Ma for muscovite VT3 $\beta$ and a biotite plateau age at $335.8 \pm 1.0$ Ma from sample VT4. Muscovite VT3 $\beta$ further shows evidence of disturbance in intermediate to high temperature steps, which could be due to a biotite inclusion, as suggested by the agreement between the corresponding apparent ages and the plateau segment at $\mathrm{c}$. $327 \mathrm{Ma}$ of the analyzed biotite from the same sample, or to the disturbance (neo/recrystallization) at c. $308.3 \pm 3.7 \mathrm{Ma}$ which is observed in the low temperature heating steps. In terms of cooling, the age difference between muscovite $\beta$ and biotite (with plateau ages at $338.3 \pm 1.1 \mathrm{Ma}$ and $327.1 \pm 0.8 \mathrm{Ma}$, respectively) for sample VT3 and the age agreement between the younger ages from the muscovite and biotite in sample VT4, suggest that the disturbance at c. $335 \mathrm{Ma}$ occurred at a temperature close to the isotopic closure window (Dunlap, 1997) of muscovite or in a temperature range between the closure temperatures for Ar diffusion in muscovite and biotite. This disturbing Mississipian event at $\mathrm{c}$. 335 Ma could reasonably be assigned to the $\mathrm{D}_{3}$ phase of the Acadian orogeny, which was inferred above from results of the La Patrie transect (low temperature disturbance in sample QC24) and by results of the Coaticook transect (QC33 and QC41). However, we prefer to interpret the ages of muscovites from sample VT3 and VT4, at c. 344-345 Ma as representing cooling following the $\mathrm{D}_{2}$ phase of the Acadian orogeny or being related to $\mathrm{D}_{3}$. Moreover, the disturbance at c. $308.3 \pm 3.7 \mathrm{Ma}$ observed in the low temperature steps of mica VT3 $\beta$ is consistent with results from the biotite in sample VT6, which yielded plateau ages at c. 304 and 298 Ma (Figure 13C). The close proximity of

This article is protected by copyright. All rights reserved 
this latter sample with the Monroe fault suggests that this fault is possibly as young as Upper Pennsylvanian and possibly related to the Alleghenian orogeny.

In summary, ${ }^{40} \mathrm{Ar} /{ }^{39} \mathrm{Ar}$ analyzes and age results of white mica and biotite grains from the $\mathrm{CVG}$ trough are consistent with a continuous and protracted evolution during three pulses of deformation related to the Acadian orogeny, and can be interpreted as follow, from north to south: (1) crystallization of $\mathrm{D}_{1}$ micas at or below isotopic closure temperature at c. $376 \mathrm{Ma}$, as preserved in southern Quebec, (2) a $\mathrm{D}_{2}$ deformation event related to (re)crystallization at c. $360 \mathrm{Ma}$, that progressively becomes more and more apparent (and penetrative) in the vicinity of the QuebecVermont border, and (3) a $\mathrm{D}_{3}$ event, at c. $335 \mathrm{Ma}$, that is mainly visible in the southeasternmost part of Quebec and in northern Vermont.

\section{DISCUSSION}

Acadian metamorphism in Quebec and New England occurs in stratigraphically correlative Silurian and Devonian rock units and varies North-South over several hundreds of $\mathrm{MPa}$ and ${ }^{\circ} \mathrm{C}$. The true thickness of these sedimentary units is not precisely known, and lateral variation in thicknesses cannot be ruled out. However, a difference in the burial and thickening between New England and southern Quebec (Armstrong et al., 1992; Tremblay et al., 2000, this study) of $\sim 20 \mathrm{~km}$ requires an explanation. Tremblay et al. (2000) proposed a tectonic model involving an irregular geometry of the collision zone and the progressive migration of metamorphic and structural fronts from south to north to account for the structural and metamorphic variations in the CVG trough. Our new data allow us to discuss the origin of the North-South metamorphic gradient suggested by Tremblay et al. (2000) and to determine its link (or not) with granitic magmatism in the CVG trough, and also its significance in terms of the tectonic evolution of the Acadian orogeny.

The formation of the CVG trough has been attributed to a Late Silurian period of crustal extension (Keppie \& Dostal, 1994; Perrot et al., 2018; Rankin et al., 2007; Tremblay \& Pinet, 2005, 2016; van Staal \& de Roo, 1995). In such a tectonic context, the existence of an elevated initial thermal state during basin formation due to, for instance, abnormal heat production from the lower crust/upper mantle, can influence the rheology of overlying crustal rocks and contributes to their thermal budget during subsequent orogenic event(s) (e.g. Vacherat et al., 2016). Although the initial thermal state of the Gaspé Belt and the CVS is poorly known, our study indicates a southward 
increase in $\mathrm{M}_{1}$ temperatures during the Acadian orogeny with a gradient of c. $25-30^{\circ} \mathrm{C} / \mathrm{km}$ (see Figure 14A). This is consistent with the suggestion of Armstrong et al. (1992) that the metamorphic style and characteristics of the CVG trough record almost no contribution from magmatic heat, and that this part of the Appalachian belt results essentially from crustal thickening during the first stages of the Acadian orogeny.

\subsection{P-T-t Data Synthesis}

Our new results combined with previously published data, allow us to constrain the tectonometamorphic evolution of the Gaspé Belt in southern Quebec. From the St-Georges to La Patrie transects, RSCM temperatures gradually increase southward, from $\sim 350^{\circ} \mathrm{C}$ to $420^{\circ} \mathrm{C}$ (Figures 7 and 14A) and are interpreted as synchronous with $M_{1}$ metamorphism and $D_{1}$ folding. This suggests that differential burial and shortening, rather than differential heating, is responsible for the metamorphic and deformation gradient. The age of $\mathrm{D}_{1}$ is constrained by ${ }^{40} \mathrm{Ar} /{ }^{39} \mathrm{Ar}$ muscovite ages from crystals that define the $\mathrm{S}_{1}$ schistosity. The peak metamorphic temperatures were well below the closure temperature for Ar diffusion in muscovite, therefore the age of c. $376 \mathrm{Ma}$ obtained in two samples is interpreted as the age of $\mathrm{D}_{1}$ (Figure 11A). In La Patrie, $\mathrm{D}_{2}$ is only slightly expressed and constrained to be around $368 \mathrm{Ma}$ by muscovite ${ }^{40} \mathrm{Ar} /{ }^{39} \mathrm{Ar}$ ages from sample QC25 (Figure.11B). Along the Coaticook transect, RSCM data show that the $500^{\circ} \mathrm{C}$ isotherm does not follows the regional $\mathrm{F}_{1}$ fold pattern, but instead it seems to be spatially controlled by the shape of the plutons (Figure 7). Also, $\mathrm{D}_{2}$ is more intensively developed than in the La Patrie transect whereas microscopic mineralogical textures suggest that the emplacement of the Averill pluton (367.8 $\pm 0.3 \mathrm{Ma}$, Perrot et al., 2018) is pre- to syn- $\mathrm{D}_{2}$. This is consistent with ${ }^{40} \mathrm{Ar} /{ }^{39} \mathrm{Ar}$ muscovite ages of c. 360 Ma recorded by several samples along the Coaticook transect (Figure 12) that constrain the $\mathrm{D}_{2}$ deformation event in that area. The calculated peak pressure for $\mathrm{D}_{1}$ along the La Patrie transect for was c. 0.4-0.6 GPa (Figure 14B), which is equal to, or higher than the maximum pressure of c. $0.4 \mathrm{GPa}$ indicated by the occurrence of andalusite in the metamorphic aureoles of plutons (Bourne, 1984, 1986a, 1986b; Erdmer, 1981). This implies that the maximum exhumation in that area was c. $0.2 \mathrm{GPa}$ (or c. $7 \mathrm{~km}$ ) which occurred between $\mathrm{D}_{1}$ at c. $376 \mathrm{Ma}$, to $\mathrm{D}_{2}$, at c. $360 \mathrm{Ma}$ in southern Quebec. Our geochronological data suggest that $\mathrm{D}_{2}$ lasted from c. 368 to c. $360 \mathrm{Ma}$ (Figure 14) in southern Québec, 
and our $\mathrm{D}_{3}$ ages are younger at around $335 \mathrm{Ma}$. The samples expressing $\mathrm{D}_{3}$ deformation are found toward the Quebec-Vermont border and in the vicinity of the Bella fault, which suggests that deformation was progressively concentrated along major fault zones in the final stages of the Acadian orogeny.

Similarly, results presented here can be used to reconstruct parts of the P-T-t-deformation path along the St.Johnsbury transect in northern Vermont. Textural evidence from garnet and biotite (Figures 5E and F), and phase equilibria modeling suggests an isothermal-burial path with late cooling for $\mathrm{D}_{1}$ in Vermont (Fig. 10). This was followed by an orogenic burial-heating path during $\mathrm{D}_{2}$ that reach peak P-T conditions of c. $625^{\circ} \mathrm{C}$ at $0.85 \mathrm{GPa}$. The first part of the P-T path, corresponding to $\mathrm{D}_{1}$ is characteristic of nappe overthrusting (Gatewood \& Stowell, 2017), during which $\mathrm{F}_{1}$ recumbent folds formed. Time constraints for the $\mathrm{D}_{1}-$ to- $\mathrm{D}_{2}$ transition are provided by data gathered south of our study area. Constraints on the timing of onset and peak metamorphism in CVS in New England are given by thermal modeling as well as monazites ages in the sedimentary sequence, and Sm-Nd ages on garnet rims in the basement rocks (Armstrong et al., 1992; Vance \& Holland, 1993; Wing et al., 2003). However, it should be noted that all these age constraints are different and based on interpretations from complex datasets and, for this reason, must be treated critically. The peak age of ca. 390 Ma suggested for $D_{1}$ metamorphism in Connecticut (Armstrong et al., 1992) is based on a modelled geothermal gradient combined with ${ }^{40} \mathrm{Ar} /{ }^{39} \mathrm{Ar}$ data, suggesting that the $\mathrm{D}_{1}$ event peaked 15 m.y. earlier in Connecticut than in southern Quebec. However, in southern Vermont, Vance and Holland (1993) produced a Sm-Nd and U-Pb garnet rim model age of c. $378 \mathrm{Ma}$, that we interpret here as being related to $D_{2}$ deformation. Alternatively, the timing of $D_{2}$ is also recorded by monazites with a dispersed age distribution, from which the best estimate for $\mathrm{D}_{2}$ is $354 \pm 9$ Ma (Wing et al., 2003). Together, these data suggest that the timing of $D_{2}$ in southern Vermont is bracketed between. $c$. 378 and $354 \mathrm{Ma}$. The last stage of folding, $\mathrm{D}_{3}$, has been attributed to an uplift of c. 0.3-0.4GPa (10-14 $\mathrm{km}$ ) on the basis of estimated P-T differences between the Chester Dome and the surrounding rock units in eastern Vermont (see Spear et al., 2002). Considering the age constraints for $\mathrm{D}_{2}, \mathrm{D}_{3}$ should have taken place after c. $354 \mathrm{Ma}$. The oldest ${ }^{40} \mathrm{Ar} /{ }^{39} \mathrm{Ar}$ plateau ages given by muscovite and biotite along the St.Johnsbury transect, are c. $345 \mathrm{Ma}$, is here interpreted here as related to the $\mathrm{D}_{3}$ exhumation as new muscovite crystals defining $S_{3}$ schistosity dominate the rock. A subsequent 
thermal event, at c. $335 \mathrm{Ma}$, is also clearly shown by our ${ }^{39} \mathrm{Ar}-{ }^{40} \mathrm{Ar}$ data (Figure 13) and can be attributed to retrograde metamorphism and/or cooling during $\mathrm{D}_{3}$ exhumation. Rocks of the CVS in Vermont record, therefore, a complex and protracted tectonometamorphic evolution spanning more than 60 m.y. Finally, Mississippian metamorphic ages $(\sim 300 \mathrm{Ma})$ are found at the Vermont-New Hampshire boundary, in the vicinity of the Monroe Fault, suggesting localized Alleghanian fault reactivation.

\subsection{Tectonic Implications for the Acadian Orogeny}

In New England, Thompson and others (1968) proposed a three-stage "nappe model" to explain the stratigraphy and the structure of the Bronson Hill Arc massif and its eastern margin, a classic model that has been largely used thereafter to describe regional deformation in the CVG trough (Harrison et al., 1989; Hatch \& Stanley, 1988; Robinson, Tucker, Bradley, Berry IV, \& Osberg, 1998; Spear et al., 2002; Tremblay et al., 2000). The progressive evolution of regional deformation, as suggested by Tremblay et al. (2000) for instance, proceeds as follows (see their Figure 9), (1) onset of recumbent folding $\left(D_{1}\right)$ and associated metamorphism $\left(M_{1}\right)$ in New England, (2) northward migration of $\mathrm{D}_{1}$ folding and Acadian metamorphism $\left(\mathrm{M}_{1}\right)$ in southern Quebec, while SE-verging deformation $\left(\mathrm{D}_{2}\right)$ was initiating in New England, and (3) northward migration of SEverging deformation $\left(D_{2}\right)$ into southern Quebec, while late stage folding $\left(D_{3}\right)$ initiated in New England. From south to north, P-T peak conditions during $\mathrm{D}_{1}$ decrease within the CVG trough, suggesting that differential burial and compression-induced exhumation of the sedimentary basin is responsible for those metamorphic (and structural) gradients (Figure 15). Hence, larger amount of thickening in the New England side of the basin would have promoted exhumation and erosion of the gravitationally unstable wedge. Such a differential crustal thickening can be attributed to crustal shortening variations due either to (1) the initial geometry of the collision zone between the converging tectonic plates, and/or (2) the presence of a buttress, the Bronson Hill Arc massif (Figure 6) for example, that would have been responsible for higher strain compression in New England.

Spear et al. (2002) argued that a peak metamorphic pressure of 0.8-1.1 GPa, measured in the core of $\mathrm{D}_{3}$ folds in New England, requires a large amount of crustal thickening (i.e. $28-35 \mathrm{~km}$ of burial). They also suggested that rocks of the CVG trough were buried beneath pre-Silurian rocks of the Bronson Hill Arc massif currently cropping out in the hanging wall of the Monroe fault. Our P-T-t

This article is protected by copyright. All rights reserved 
data are consistent with this hypothesis. Our data suggest that the NW-directed thrusting of an originally laterally discontinuous Bronson Hill Arc could have accounted for lateral metamorphic variations within the CVG trough, and that it may have acted as a tectonic buttress against the New York promontory to the south, that forced a deepest burial and more intense $\mathrm{D}_{1}$ shortening in New

England as compared to the Quebec reentrant (including southern Quebec and Gaspé Peninsula), progressing from South to North. Continuing crustal compression and thickening led to the melting of the lower crust and then resulted in the emplacement of granitic intrusions, respectively in the middle and the upper crust in northern New England and southern Quebec during the Late Devonian. At c. $378 \mathrm{Ma}, \mathrm{D}_{2}$ deformation was initiated in Vermont, and propagated northward in southern Quebec where it started around c. 368-to-360 Ma. However, during the time D2 was vanishing in southern Quebec, it continued and reached its climax in Vermont. The late stage, $\mathrm{D}_{3}$, then followed the climax of $D_{2}$ in Vermont and consists of regional superposed $F_{3}$ folding that induced crustal exhumation starting around $345 \mathrm{Ma}$. Protracted crustal deformation associated with $\mathrm{D}_{3}$ likely became concentrated at the boundary between the CVG trough and the Bronson Hill Arc along major regional faults such as the Bella, Monroe and the Westminster-West faults (see McWilliams et al., 2013), around $335 \mathrm{Ma}$.

\section{CONCLUSION}

Deformational phases recorded by the CVG trough and the CVS indicate a longer and younger residence time at high-temperatures and pressures in the southern part of the basin compared with the north. We suggest a progressive and incremental deformation model, involving three phases of crustal deformation $\left(\mathrm{D}_{1}-\mathrm{D}_{3}\right)$ during the Acadian orogeny which explains the tectonic evolution of the CVG trough. The North-South trending asynchronous deformation and metamorphism documented here started around $390 \mathrm{Ma}$ in central New England (i.e. Massachussetts) with a crustal thickening and deformation event $\left(D_{1}\right)$ that progressively migrated northward into southern Quebec where it peaked at c. $0.6 \mathrm{GPa} / 380^{\circ} \mathrm{C}$ at around $375 \mathrm{Ma}$. A regional-scale plutonic event occurred both in southern Quebec and Vermont and was more or less coeval with a crustal compression event $\mathrm{D}_{2}$. This compressional event caused crustal burial in Vermont resulting in prograde metamorphic conditions of up to c. $0.85 \mathrm{GPa} / 630^{\circ} \mathrm{C}$ from 378 to $355 \mathrm{Ma}$ and induced low grade metamorphic recrystallization in southern Quebec around c. 368-360 Ma. $\mathrm{D}_{1}$ and $\mathrm{D}_{2}$ led to deeper burial in Vermont than in Quebec.

This article is protected by copyright. All rights reserved 
This was followed by a $\mathrm{D}_{3}$ deformation event that led to the exhumation of this deeply buried material around 345-335 Ma in Vermont.

Our results suggest that Acadian deformation formed part of a c. 60 m.y. continuum of plate convergence during the Middle and Late Devonian. The along-strike progression of the first deformation event $\left(D_{1}\right)$ took approximately 15-10 m.y to migrate from central New England to southern Quebec, which leads to a propagation rate of $\sim 35-50 \mathrm{~km} . \mathrm{Myrs}^{-1}$, which is, for instance, in the same order of magnitude as deformation propagation rates proposed for the Penglai orogeny in Taiwan (Ramsey, Walker, \& Jackson, 2007).

Our study helps to constrain the nature of geodynamic processes involved in the structural evolution of the CVG trough. The higher volume of granitic intrusions in Vermont compared with southern Quebec is consistent with the exhumation of lower crust in this area and also with a higher amount of heat production within the most thickened parts of the Acadian wedge. From south to north, the tectonic burial of the sedimentary rocks of the CVG trough during the Acadian orogeny varied from approximately $30 \mathrm{~km}$ in New England, to c. $10 \mathrm{~km}$ in southern Quebec and less than $5 \mathrm{~km}$ in the Gaspé Peninsula. The differential thickening and exhumation rates of the CVG trough are interpreted here as resulting from interactions with major crustal indenters (or buttresses) in New England, such as the New York Promontory and/or the Bronson Hill Massif that reduced the effective width needed to accommodate crustal deformation.

\section{ACKOWNLEDGEMENTS}

This contribution is part of the first author's Ph. D. thesis at the Universite du Quebec à Montreal (UQAM). We sincerely thank Olivier Beyssac for access to the Raman spectroscopy facilities, and financial support of the Institut des Sciences de la Terre de Paris (ISTEP). Thanks are due to J. Kim for his field guidance in northern Vermont, and to M. Vincent-Couture for her assistance during fieldwork and sampling. Joshua Davies, Stéphane De Souza, Jean David, Keith Klepeis and Michel Malo are gratefully acknowledged for providing comments and constructive reviews of an earlier version of the manuscript. We thank Bob Wintsch and Chris Gerbi for helpful and constructive comments. This study was supported by the Natural Sciences and Engineering Research Council of Canada (NSERC) through an operating grant (PG-105669) to A. Tremblay. M.

This article is protected by copyright. All rights reserved 
Perrot benefited of additional funding from Geotop graduate student grants in 2015, 2016 and 2017. There is no conflict of interest to declare.

This article is protected by copyright. All rights reserved 


\section{References}

Aleinikoff, J. N., Ratcliffe, N. M., \& Walsh, G. J. (2011). Provisional zircon and monazite uranium-lead geochronology for selected rocks from Vermont. (2011-1309). US Geological Survey.

Alexandrov, P., Ruffet, G., \& Cheilletz, A. (2002). Muscovite recrystallization and saddle-shaped 40 Ar/39 Ar age spectra: example from the Blond granite (Massif Central, France). Geochimica et Cosmochimica Acta, 66(10), 1793-1807.

Anderson, M., \& Coish, R. (1999). Depth constraints on the origin of Northeast Kingdom granites. Paper presented at the Geological Society of America, Abstracts with Programs.

Aoya, M., Kouketsu, Y., Endo, S., Shimizu, H., Mizukami, T., Nakamura, D., \& Wallis, S. (2010). Extending the applicability of the Raman carbonaceous - material geothermometer using data from contact metamorphic rocks. Journal of Metamorphic Geology, 28(9), 895-914.

Armstrong, T., Tracy, R., \& Hames, W. (1992). Contrasting styles of Taconian, eastern Acadian and western Acadian metamorphism, central and western New England. Journal of Metamorphic Geology, 10(3), 415-426.

Arth, J. G., \& Ayuso, R. A. (1997). The Northeast Kingdom batholith, Vermont: Geochronology and Nd, O, Pb, and Sr isotopic constraints on the origin of Acadian granitic rocks. In : The Nature of Magmatism in the Appalachian Orogen eds Sinha, A. K., Whalen, J.B. and Hogan, J. P. . Geological Society of America Memoirs, 191, 1-18.

Asselin, E. (2002). Rapport préliminaire sur les résultats palynologiques obtenus pour des séries d'échantillons provenant du Siluro-Dévoniens de l'Estrie et de la Beauce du sud du Québec. Internal Geological Survey of Canada report.

Beyssac, O., Goffé, B., Chopin, C., \& Rouzaud, J. (2002). Raman spectra of carbonaceous material in metasediments: a new geothermometer. Journal of Metamorphic Geology, 20(9), 859-871.

Bourne, J. (1984). Géologie du complexe granitique du Lac-aux-Araignées (MB 84-22). Ministère de l'Énergie et des Ressources Naturelles, Québec.

Bourne, J. (1986a). Géologie du complexe granitique d'Aylmer - Estrie. (MB 86-40). Ministère de l'Énergie et des Ressources Naturelles, Québec.

Bourne, J. (1986b). Géologie du complexe granitique de Saint-Sébastien-Sainte-Cécile - Estrie. (MB 86-41). Ministère de l'Énergie et des Ressources Naturelles, Québec.

Bourque, P.-A., Malo, M., \& Kirkwood, D. (2000). Paleogeography and tectono-sedimentary history at the margin of Laurentia during Silurian to earliest Devonian time: The Gaspé Belt, Québec. Geological Society of America Bulletin, 112(1), 4-20.

Bourque, P., Brisebois, D., \& Malo, M. (1995). Gaspé belt. Geology of the Appalachian-Caledonian Orogen in Canada and Greenland. Edited by H. Williams. Geological Survey of Canada, Geology of Canada(6), 316-351.

Bradley, D. C., Tucker, R. D., Lux, D. R., Harris, A. G., \& McGregor, D. C. (2000). Migration of the Acadian orogen and foreland basin across the northern Appalachians of Maine and adjacent areas. (no. 1615). US Geological Survey. 
Castonguay, S., Ruffet, G., \& Tremblay, A. (2007). Dating polyphase deformation across low-grade metamorphic belts: An example based on 40Ar/39Ar muscovite age constraints from the southern Quebec Appalachians, Canada. Geological Society of America Bulletin, 119(7-8), 978-992.

Cheilletz, A., Ruffet, G., Marignac, C., Kolli, O., Gasquet, D., Féraud, G., \& Bouillin, J. (1999). 40Ar/39Ar dating of shear zones in the Variscan basement of Greater Kabylia (Algeria). Evidence of an Eo-Alpine event at $128 \mathrm{Ma}$ (Hauterivian-Barremian boundary): geodynamic consequences. Tectonophysics, 306(1), 97-116.

Connolly, J., \& Petrini, K. (2002). An automated strategy for calculation of phase diagram sections and retrieval of rock properties as a function of physical conditions. Journal of Metamorphic Geology, 20(7), 697-708.

Connolly, J. A. (2005). Computation of phase equilibria by linear programming: a tool for geodynamic modeling and its application to subduction zone decarbonation. Earth and Planetary Science Letters, 236(1), 524-541.

Dietsch, C., \& Sutter, J. (1987). Tectonic and metamorphic evolution of western Connecticut as interpreted from $40 \mathrm{Ar} / 39 \mathrm{Ar}$ data. Paper presented at the Geological Society of America Abstracts with Programs.

Dorais, M. J., Marvinney, R. G., \& Markert, K. (2017). The age, petrogeneis and tectonic significance of the Frontenac Formation basalts, northern New Hampshire and western Maine. American Journal of Science, 317(9), 990-1018.

Dunlap, W. (1997). Neocrystallization or cooling? 40Ar/39Ar ages of white micas from low-grade mylonites. Chemical Geology, 143(3-4), 181-203.

Erdmer, P. (1981). Metamorphism at the northwest contact of the Stanhope pluton, Quebec Appalachians: Mineral equilibria in interbedded pelite and calc-schist. Contributions to Mineralogy and Petrology, 76(1), 109-115.

Evans, T. (2004). A method for calculating effective bulk composition modification due to crystal fractionation in garnet - bearing schist: implications for isopleth thermobarometry. Journal of Metamorphic Geology, 22(6), 547557.

Ferry, J. M. (1994). Overview of the petrologic record of fluid flow during regional metamorphism in northern New England. American Journal of Science, 294(8), 905-988.

Ferry, J. M. (2000). Patterns of mineral occurrence in metamorphic rocks. American Mineralogist, 85(11-12), 1573-1588.

Gatewood, M., \& Stowell, H. H. (2017). Thrust loading as a mechanism for crustal recycling: An example from the Swakane Gneiss, Cascades crystalline core, Washington, USA. Linkages and Feedbacks in Orogenic Systems: Geological Society of America Memoir, 213, 255-278.

Gerbi, C., Johnson, S., \& Aleinikoff, J. (2006). Origin and orogenic role of the Chain Lakes massif, Maine and Quebec. Canadian Journal of Earth Sciences, 43(3), 339-366.

Hannula, K., Lackey, J., Mattox, E., McGrath, G., Onasch, E., \& Wertheim, J. (1999). Syn-tectonic pluton intrusion during contractional deformation: microstructural and metamorphic evidence from the aureole of the Acadian Victory Pluton, north-eastern Vermont, USA. Journal of Metamorphic Geology, 17, 271-286.

Harrison, T. M., Spear, F. S., \& Heizler, M. T. (1989). Geochronologic studies in central New England II: Post-Acadian hinged and differential uplift. Geology, 17(2), 185-189.

This article is protected by copyright. All rights reserved 
Hatch, N. L., \& Stanley, R. S. (1988). Post-Taconian structural geology of the Rowe-Hawley zone and the Connecticut Valley belt west of the Mesozoic basins. US Geological survey professional paper; 1366-C.

Holland, T., \& Powell, R. (1998). An internally consistent thermodynamic data set for phases of petrological interest. Journal of Metamorphic Geology, 16(3), 309-343.

Hueber, F. M., Bothner, W. A., Hatch, N. L., Finney, S. C., \& Aleinikoff, J. N. (1990). Devonian plants from southern Quebec and northern New Hampshire and the age of the Connecticut Valley trough. American Journal of Science, 290(4), 360-395. doi:10.2475/ajs.290.4.360

Jourdan, F., \& Renne, P. R. (2007). Age calibration of the Fish Canyon sanidine 40Ar/39Ar dating standard using primary $\mathrm{K}-\mathrm{Ar}$ standards. Geochimica et Cosmochimica Acta, 71(2), 387-402.

Jourdan, F., Verati, C., \& Féraud, G. (2006). Intercalibration of the Hb3gr 40Ar/39Ar dating standard. Chemical Geology, 231(3), 177-189.

Keppie, J. D., \& Dostal, J. (1994). Late Silurian - Early Devonian transpressional rift origin of the Quebec Reentrant, northern Appalachians: Constraints from geochemistry of volcanic rocks. Tectonics, 13(5), 1183-1189.

Kohn, M. J., \& Spear, F. S. (1990). Two new geobarometers for garnet amphibolites, with applications to southeastern Vermont. American Mineralogist, 75(1-2), 89-96.

Kuiper, Y. D. (2016). Development of the Norumbega fault system in mid-Paleozoic New England, USA: An integrated subducted oceanic ridge model. Geology, 44(6), 455-458.

Lafrance, B. (1995). Nouvelles données stratigraphiques et structurales dans la partie sur-est du synclinorium de Connecticut Valley-Gaspé, Appalaches du Sud du Québec. (Maitrise en Sciences de la Terre), Université du Québec, INRS-Géoressiources,

Lagor, S. W. (2016). The relationship between magmatism and deformation during the Acadian orogeny: a case study from eastern-central Vermont. (Master of Sciences), University of Vermont,

Laird, J., \& Albee, A. L. (1981). Pressure, temperature, and time indicators in mafic schist; their application to reconstructing the polymetamorphic history of Vermont. American Journal of Science, 281(2), 127-175.

Laird, J., Lanphere, M. A., \& Albee, A. L. (1984). Distribution of Ordovician and Devonian metamorphism in mafic and pelitic schists from northern Vermont. American Journal of Science, 284(4-5), 376-413.

Lavoie, D. (2004). The Lower Devonian Compton Formation in southern Quebec: from delta front to pro-delta sedimentation. Canadian Journal of Earth Sciences, 41(5), 571-585.

Lavoie, D., \& Asselin, E. (2004). A new stratigraphic framework for the Gaspé Belt in southern Quebec: implications for the pre-Acadian Appalachians of eastern Canada. Canadian Journal of Earth Sciences, 41(5), 507-525.

Law, R. D. (2014). Deformation thermometry based on quartz c-axis fabrics and recrystallization microstructures: A review. Journal of Structural Geology, 66, 129-161.

Malo, M., Tremblay, A., Kirkwood, D., \& Cousineau, P. (1995). Along - strike Acadian structural variations in the Québec Appalachians: Consequence of a collision along an irregular margin. Tectonics, 14(6), 1327-1338.

This article is protected by copyright. All rights reserved 
Massey, M. A., Moecher, D. P., Walker, T. B., O'Brien, T. M., \& Rohrer, L. P. (2017). The role and extent of dextral transpression and lateral escape on the post-Acadian tectonic evolution of south-central New England. American Journal of Science, 317(1), 34-94.

McWilliams, C. K., Kunk, M. J., Wintsch, R. P., \& Bish, D. L. (2013). Determining ages of multiple muscovite-bearing foliations in phyllonites using the 40Ar/39Ar step heating method: Applications to the Alleghanian orogeny in central New England. American Journal of Science, 313(10), 996-1016.

McWilliams, C. K., Walsh, G. J., \& Wintsch, R. P. (2010). Silurian-Devonian age and tectonic setting of the Connecticut Valley-Gaspé trough in Vermont based on U-Pb SHRIMP analyses of detrital zircons. American Journal of Science, 310(5), 325-363.

Menard, T., \& Spear, F. S. (1993). Metamorphism of calcic pelitic schists, Strafford Dome, Vermont: compositional zoning and reaction history. Journal of Petrology, 34(5), 977-1005.

Moench, R. (1993). Highlights of metamorphic stratigraphy and tectonics in western Maine to northeastern Vermont. Field trip guidebook for the northeastern United States, 01-32.

Moench, R. H., \& Aleinikoff, J. N. (2003). Stratigraphy, geochronology, and accretionary terrane settings of two Bronson Hill arc sequences, northern New England. Physics and Chemistry of the Earth, Parts A/B/C, 28(1), 113-160.

Osberg, P. H., Tull, J.F., Robinson, P., Hon, R., Butler, J. R. . (1989). The Acadian orogen. In T. G. S. o. America (Ed.), The Appalachian-Ouachita orogen in theUnited States (Vol. F-2, pp. 179-232): R.D. Hatcher, Jr, W. A. Thomas and G. W. Viele.

Perrot, M. (2018). Évolution tectonique des bassins sédimentaires tardi-à-post-taconiens des Appalaches du sud du Québec et du nord du Vermont. (Ph.D.), Uqam,

Perrot, M., \& Tremblay, A. (2017). Compilation et révision géologique des régions de Drummonville, Richmond, MontOrford, Grandby, Cowansville et du Lac-Memphrémagog. 1/50 000

Perrot, M., Tremblay, A., Ruffet, G., \& David, J. (2018). Detrital U-Pb and 40Ar/39Ar geochronology of the Connecticut Valley-Gaspé trough, southern Quebec and northern Vermont-Transitional tectonism from Salinic to Acadian orogenic cycles. Tectonophysics, 745, 430-452.

Ramsey, L. A., Walker, R. T., \& Jackson, J. (2007). Geomorphic constraints on the active tectonics of southern Taiwan. Geophysical Journal International, 170(3), 1357-1372.

Rankin, D., Coish, R., Tucker, R., Peng, Z., Wilson, S., \& Rouff, A. (2007). Silurian extension in the Upper Connecticut Valley, United States and the origin of middle Paleozoic basins in the Quebec embayment. American Journal of Science, 307(1), 216-264.

Rankin, D., \& Tucker, R. (2009). Bronson Hill and Connecticut Valley sequences in the Stone Mountain area, Northeast Kingdom, Vermont. Paper presented at the Guidebook for Field Trips in the Northeast Kingdom of Vermont and Adjacent Regions: New England Intercollegiate Geological Conference, 101st Annual Meeting: Lyndonville, Vermont, Lyndon State College.

This article is protected by copyright. All rights reserved 
Rankin, D. W., Tucker, R. D., \& Amelin, Y. (2013). Reevaluation of the Piermont-Frontenac allochthon in the Upper Connecticut Valley: Restoration of a coherent Boundary Mountains-Bronson Hill stratigraphic sequence. Geological Society of America Bulletin, 125(5-6), 998-1024.

Renne, P. R., Balco, G., Ludwig, K. R., Mundil, R., \& Min, K. (2011). Response to the comment by WH Schwarz et al. on "Joint determination of $40 \mathrm{~K}$ decay constants and $40 \mathrm{Ar} * / 40 \mathrm{~K}$ for the Fish Canyon sanidine standard, and improved accuracy for 40Ar/39Ar geochronology” by PR Renne et al.(2010). Geochimica et Cosmochimica Acta, 75(17), 5097-5100.

Renne, P. R., Mundil, R., Balco, G., Min, K., \& Ludwig, K. R. (2010). Joint determination of 40K decay constants and $40 \mathrm{Ar} * / 40 \mathrm{~K}$ for the Fish Canyon sanidine standard, and improved accuracy for 40Ar/39Ar geochronology. Geochimica et Cosmochimica Acta, 74(18), 5349-5367.

Richter, D. (1987). Barre granite quarries, Barre, Vermont. In D. C. Roy, (ed.) (Ed.), Centennial Field Guide (Vol. 5, pp. p. 239-242.): Boulder, CO, Geological Society of America.

Robinson, P., Tucker, R. D., Bradley, D., Berry IV, H. N., \& Osberg, P. H. (1998). Paleozoic orogens in New England, USA. GFF, 120(2), 119-148.

Roddick, J. (1983). High precision intercalibration of 40Ar-39Ar standards. Geochimica et Cosmochimica Acta, 47(5), 887-898.

Roy, S. (2008). Maturation thermique et potentiel pétroligène de la ceinture de Gaspé, Gaspésie, Québec, Canada. Université du Québec, Institut national de la recherche scientifique,

Ruffet, G., Féraud, G., \& Amouric, M. (1991). Comparison of 40Ar-39Ar conventional and laser dating of biotites from the North Trégor Batholith. Geochimica et Cosmochimica Acta, 55(6), 1675-1688.

Ruffet, G., Féraud, G., Balèvre, M., \& Kiénast, J.-R. (1995). Plateau ages and excess argon in phengites: an $40 \mathrm{Ar} 39 \mathrm{Ar}$ laser probe study of Alpine micas (Sesia Zone, Western Alps, northern Italy). Chemical Geology, 121(1), 327343.

Ruffet, G., Gruau, G., Ballèvre, M., Féraud, G., \& Philippot, P. (1997). Rb Sr and 40Ar $\quad$ 39Ar laser probe dating of high-pressure phengites from the Sesia zone (Western Alps): underscoring of excess argon and new age constraints on the high-pressure metamorphism. Chemical Geology, 141(1-2), 1-18.

Simonetti, A., \& Doig, R. (1990). U-Pb and Rb-Sr geochronology of Acadian plutonism in the Dunnage zone of the southeastern Quebec Appalachians. Canadian Journal of Earth Sciences, 27(7), 881-892.

Spear, F. S., Kohn, M., Cheney, J. T., \& Florence, F. (2002). Metamorphic, thermal, and tectonic evolution of central New England. Journal of Petrology, 43(11), 2097-2120.

Tartese, R., Ruffet, G., Poujol, M., Boulvais, P., \& Ireland, T. R. (2011). Simultaneous resetting of the muscovite K - Ar and monazite U - Pb geochronometers: a story of fluids. Terra Nova, 23(6), 390-398.

Tremblay, A., De Souza, S., Perrot, M., \& Theriault, R. (2015). Géologie des Appalaches du Québec, Feuillet Sud-Ouest, regions de Montérégie, Cantons de l’Est, Centre-du-Québec et Chaudière-Appalaches. 1:300,000.

This article is protected by copyright. All rights reserved 
Tremblay, A., \& Pinet, N. (2005). Diachronous supracrustal extension in an intraplate setting and the origin of the Connecticut Valley-Gaspé and Merrimack troughs, northern Appalachians. Geological Magazine, 142(1), 7-22.

Tremblay, A., \& Pinet, N. (2016). Late Neoproterozoic to Permian tectonic evolution of the Quebec Appalachians, Canada. Earth-Science Reviews, 160, 131-170.

Tremblay, A., Ruffet, G., \& Castonguay, S. (2000). Acadian metamorphism in the Dunnage zone of southern Québec, northern Appalachians: 40Ar/39Ar evidence for collision diachronism. Geological Society of America Bulletin, 112(1), 136-146.

Tucker, R., Osberg, P., \& Berry, H. (2001). The geology of a part of Acadia and the nature of the Acadian orogeny across central and eastern Maine. American Journal of Science, 301(3), 205-260.

Tucker, R. D., \& Robinson, P. (1990). Age and setting of the Bronson Hill magmatic arc: A re-evaluation based on U-Pb zircon ages in southern New England. Geological Society of America Bulletin, 102(10), 1404-1419.

Turner, G. (1971). Argon 40-argon 39 dating: The optimization of irradiation parameters. Earth and Planetary Science Letters, 10(2), 227-234.

Vacherat, A., Mouthereau, F., Pik, R., Bellahsen, N., Gautheron, C., Bernet, M., . . . Pinna Jamme, R. (2016). Rift - to - collision transition recorded by tectonothermal evolution of the northern Pyrenees. Tectonics, 35(4), 907-933.

van Staal, C., \& de Roo, J. (1995). Mid-Paleozoic tectonic evolution of the Appalachian Central Mobile Belt in northern New Brunswick, Canada: collision, extensional collapse and dextral transpression. Current perspectives in the Appalachian-Caledonian Orogen. Edited by JP Hibbard, CR van Staal, and PA Cawood. Geological Association of Canada, Special Paper, 41, 367-389.

Vance, D., \& Holland, T. (1993). A detailed isotopic and petrological study of a single garnet from the Gassetts Schist, Vermont. Contributions to Mineralogy and Petrology, 114(1), 101-118.

Walsh, G. J., Kim, J., Gale, M. H., \& King, S. M. (2010). Bedrock geologic map of the Montpelier and Barre West quadrangles, Washington and Orange counties, Vermont. 1:24000

Westerman, D., \& Coish, R. (2009). Geochemistry and emplacement style in Acadian plutons between Woodbury and Northfield, Vermont. In Guidebook for Field Trips in the Northeast Kingdom of Vermont and Adjacent Regions (Vol. C-5, pp. 261 274.): Westerman, D. S., \& Lathrop, A. S.

White, W. S., \& Jahns, R. H. (1950). Structure of central and east-central Vermont. The Journal of Geology, 179-220.

Wing, B. A., Ferry, J. M., \& Harrison, T. M. (2003). Prograde destruction and formation of monazite and allanite during contact and regional metamorphism of pelites: petrology and geochronology. Contributions to Mineralogy and Petrology, 145(2), 228-250.

Wintsch, R., Kunk, M., Boyd, J., \& Aleinikoff, J. (2003). PTt paths and differential Alleghanian loading and uplift of the Bronson Hill terrane, south central New England. American Journal of Science, 303(5), 410-446.

This article is protected by copyright. All rights reserved 


\section{LIST OF SUPPORTING INFORMATION}

Appendix S1. Methodology and analytical techniques

Table S1. sample locations, correlation between analyses number and field sample numbers

Table S2. Raman Spectrometry on Carbonaceous minerals analyzes

Table S3. Representative electron microprobe mineral data

Table S4. ${ }^{40} \mathrm{Ar} /{ }^{39} \mathrm{Ar}$ Data

Figure S1. Metamorphic minerals assemblages in the Compton/Gile Mountain formations for samples analyzed during our study. Dashed lines are for minerals present in a pervasive way. Orange shaded rows are for samples modeled by IPDS discussed in the text, whereas grey shaded rows are for those presented in supplementary material. Representative samples have been plotted on the AFM diagram. See supplementary data for GPS location (Table S1).

Figure S2. Results of phase equilibria modelling for sample QC11 presented as isochemical phase diagram sections. A) Phase equilibria and bulk rock composition. Color code for field variance (darker color for higher variance fields). B) Si compositional isopleths for phengite. RSCM T is highlighted in yellow. The inferred P-T conditions for peak metamorphism are shown in red.

Figure S3. Results of phase equilibria modelling for sample QC22 presented as isochemical phase diagram sections. A) Phase equilibria and bulk rock composition. Color code for field variance (darker color for higher variance fields). B) Si compositional isopleths for phengite. RSCM T is highlighted in yellow. The inferred P-T conditions for peak metamorphism are shown in red.

Figure S4. Results of phase equilibria modelling for sample VT2 presented as isochemical phase diagram sections. A) Phase equilibria and bulk rock composition. Color code for field variance (darker color for higher variance fields). B) Garnet, biotite isopleths thermobarometry. Red field is for intersect of garnet core isopleths and open red field is for garnet rim, biotite phengite and plagioclase isopleths thermobarometry intersect which is compatible with the peak metamorphism paragenesis. Chemical compositional ranges are detailed under each concerned phase equilibria diagram.

This article is protected by copyright. All rights reserved 


\section{FIGURE CAPTIONS}

Figure 1. A) Simplified lithotectonic map of the Northern Appalachians of mainland Canada and New England (modified from Hibbard and others, 2006). B) Geologic map of the Gaspé Belt in southern Quebec and of the Connecticut Valley sequence (CVS) in northern Vermont (Modified after McWilliams et al., 2010; Rankin et al., 2013, Tremblay et al., 2015). See (A-A') to (D-D') crosssections on Figure 2. White stars are for ${ }^{40} \mathrm{Ar} /{ }^{39} \mathrm{Ar}$ samples location and black stars are for isochemical phase diagram section (IPDS) samples presented in the text. CD - Chester Dome. CGV trough - Connecticut Valley-Gaspé trough. CLM - Chain Lake Massif. MF - Monroe Fault. RMC Richardson Memorial Contact. Plutons: AYL - Lac Aylmer, WIN - Winslow, SS - Saint-Sébastien Sainte-Cécile, SC - Scotstown, LAA - Lac-aux-Araignées, EH - East Hereford, AV - Averill, DB Derby, NU - Nulhegan, WIL - Willoughby, VIC - Victoria, KN - Knox Mountain, BA - Barre.

Figure 2. Schematic cross-sections of the Connecticut Valley-Gaspé (CVG) trough in southern Quebec and northern Vermont. Southern Quebec - (A-A') St-Georges, (B-B') La Patrie, and (C-C') Coaticook transects. Northern Vermont - (D-D') St.Johnsbury transect, the latter profile has been inspired by, and modified from Hatch and Stanley (1988) and Ratcliff et al. (2011). See Figure 1 for color symbols color and locations. BF - Bella fault. CHT - Coburn Hill Thrust. DRF - Dog River Fault. LGF-La Guadeloupe Fault. MF - Monroe Fault. RMC - Richardson Memorial Contact. SSF Sandy stream Fault. WF - Woburn Fault.

Figure 3. A) $F_{1}$ folds as preserved in the Ayer's Cliff Formation, north of La Patrie transect. B) SE-verging overturned $F_{2}$ folds in the Ayer's Cliff Formation along the Coaticook transect. C) $S_{2}$ and $S_{3}$ crenulation schistosities in Milan member of the Compton Formation along the Coaticook transect. D) $F_{1}$ and $F_{2}$ folds in the Compton Formation within the metamorphic aureole of the East-Hereford pluton, Coaticook transect. E) $F_{1 / 2}$ fold in impure limestones of the Waits River Formation along the St.Johnsbury transect. F) $F_{1 / 2}$ and $F_{3}$ folds in calcareous sandstone of the Waits River Formation along the St.Johnsbury transect. The red square highlights a coin for scale. Names of the deformational phases as used in specific areas (southern Quebec and northern New England Vermont) are utilized.

Figure 4. A) Foliation trajectory map for the CVG trough in southern Quebec. Note the arcuate shape of the $S_{2}$ schistosity trajectories. B) Stereographic diagrams $S_{o}$ and the various structural fabrics $\left(S_{1}\right.$,

This article is protected by copyright. All rights reserved 
$\mathrm{S}_{2}$ and $\mathrm{S}_{3}$ ) for the La Patrie and Coaticook transects. Lower hemisphere, equal area projections. See text for discussion. Ce: Center of the basin. Bo: Eastern and western borders of the basin.

Figure 5. Microphotographs for metamorphic rocks of the Compton and Gile Mountain formations along the La Patrie (A), Coaticook (B and C) and St.Johnsbury (D, E and F) transects. A) Sample QC23, a quartz-mica-chlorite metawacke; a well-developed $\mathrm{S}_{1}$ schistosity is marked by grain flattening and white mica alignments. Note a preserved detrital texture in quartz, and grain boundary bulging recrystallization textures (BLG). B) and C) Sample QC40, a quartz-mica-biotite-staurolitechlorite metawacke from the metamorphic aureole of the Averill pluton. The $\mathrm{S}_{2}$ cleavage wraps around biotite and staurolite porphyroblasts. Note that some biotite grains preserved $\mathrm{S}_{1}$. D), E) and F) Sample VT1, a fine-grained biotite-garnet schist; D) shows a biotite porphyroblast preserving $\mathrm{S}_{1}$ within it and wrapped by the $S_{2}$ foliation., D) and F) shows garnet porphyroblasts showing 2 events of crystallisation $\left(\mathrm{Gt}_{1}\right.$ and $\left.\mathrm{Gt}_{2}\right)$ separated by chlorite growth. Note the shared crystal faces between the second generation of garnet and biotite in $\mathrm{E}$, and the $\mathrm{S}_{2}$ schistosity wrapping around the garnet in $\mathrm{F}$.

Figure 6. A) Map of New England and Quebec Appalachians showing the global distribution of Acadian metamorphic grade in the CVG trough. B) Distribution of Acadian metamorphic isograds (Laird, Lanphere, \& Albee, 1984; Osberg, 1989) and isotherms (this study) in the CVG trough of southern Quebec and northern New England. BHA, Bronson Hill Anticlinorium; CVGT, Connecticut Valley-Gaspé trough; MWA Munsungun-Winterville Arch; WLA, Weeksboro-Lunksoos Arch.

Figure 7. Map of southern Quebec showing the variations of RSCM temperatures. Bold circle and bold Qc numbers are for RSCM samples for which IPDS modeling and ${ }^{40} \mathrm{Ar} /{ }^{39} \mathrm{Ar}$ thermochronology has been performed and are presented in the text. Italic numbers are for RSCM temperatures. An extrapolation of some of the isotherm lines was made. Dashed orange lines around plutons are mostly based on field observations. Black circles are for samples that could not have been analyzed because of very-poorly disordered graphitic carbon. Light grey and medium grey areas are for Devonian and Cretaceous intrusions respectively.

Figure 8. Garnet chemistry for sample VT1 showing the compositional variations from core to rim and the corresponding representative spessartine map.

Figure 9. Isochemical phase-diagram section and corresponding bulk rock composition for sample QC23. Colour code for field variance (darker colour for higher variance fields). Si compositional isopleths for phengite are superimposed on the section. RSCM T is highlighted in

This article is protected by copyright. All rights reserved 
yellow. Inferred P-T conditions are shown in pale grey. The inferred P-T conditions for peak metamorphism are shown in red.

Figure 10. Results of phase equilibria modelling for sample VT1 presented as isochemical phase diagram sections. A) Phase equilibria and bulk rock composition. Color code for field variance (darker color for higher variance fields). B) Garnet isopleths thermobarometry. Red field is for intersect of garnet core isopleths and open red field is for garnet rim isopleths thermobarometry intersect which is compatible with the peak metamorphism paragenesis. Explanation of lines are under each concerned phase equilibria diagram.

Figure 11. ${ }^{40} \mathrm{Ar} /{ }^{39} \mathrm{Ar}$ age spectra and frequency diagram (density probability diagram) for micas of the Lac-Mégantic area - (A) sample QC11 and of the La Patrie transect — samples (B)

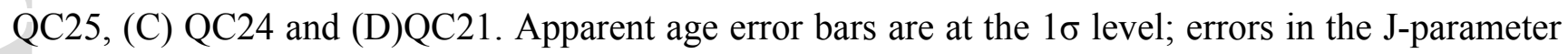
are not included. Plateau and pseudo-plateau ages $(1 \sigma$ uncertainties including errors in the Jparameter) are given when applicable. Age error of fusion step of experiment QC25 $\chi(368.3 \pm 2.3$ Ma; bold line in Figure 11 B) includes errors on J-parameter. See text for discussion.

Figure 12. ${ }^{40} \mathrm{Ar} /{ }^{39} \mathrm{Ar}$ age spectra for micas of the Coaticook transect - samples (A) QC49, (B) QC40 and QC41, (C) QC33. Refer to Figure 11 for details on errors. Solid and dashed bold line frame saddle of age spectrum QC49 $\delta$. The solid bold end segments frame apparent ages of the saddle flanks from which the minimum age of the former radiogenic component is estimated. This age is indicated above $(359.5 \pm 4.3 \mathrm{Ma})$. Bold dashed central segment frames apparent ages impacted by the degassing of the radiogenic component from the recrystallized phase. See text for discussion.

Figure 13. ${ }^{40} \mathrm{Ar} /{ }^{39} \mathrm{Ar}$ age spectra for micas of the St.Johnsbury transect — samples (A) VT3, (B) VT4, (C) VT6. Refer to Figure 14 for details on errors. Solid and dashed bold lines frame saddles of age spectra. The solid bold end segments frame apparent ages of the saddle flanks from which minimum ages of former radiogenic components are estimated. These ages are indicated above (e.g. VT4 $\alpha$ or $\beta$ : $345.3 \pm 0.9 \mathrm{Ma}$ or $344.0 \pm 1.4 \mathrm{Ma}$ ). Bold dashed central segments define apparent ages impacted by the degassing of the radiogenic components from the recrystallized phases. When considered significant, the pseudo-plateau or apparent ages of the saddle basements are indicated below (e.g. VT4 $\alpha$ or $\beta$ : $336.9 \pm 2.1$ Ma or $335.8 \pm 0.7 \mathrm{Ma}$ ). See text for discussion.

This article is protected by copyright. All rights reserved 
Figure 14. Data synthesis. (A). North-south variations of metamorphic temperatures (B), pressures (C) and ages (C) between southern Quebec and Vermont. Colored data are from this study, open and grey symbol are from the literature (Aleinikoff et al., 2011; Dietsch \& Sutter, 1987; Ferry, 2000; Kohn \& Spear, 1990; Lagor, 2016; McWilliams et al., 2013; Menard \& Spear, 1993; Perrot et al., 2018; Simonetti \& Doig, 1990; Wing et al., 2003). Only concordant ages are reported for plutonism. The location of reference is the northernmost Raman spectrometry sample of the study area but the location of samples south of central Vermont is approximative. WWFZ; Westminster West Fault Zone.

Figure 15. 3D sketch showing the inferred structural state of metamorphic rocks of the CVG trough in southern Quebec and New England towards the end of the Acadian orogeny and transition(?) to the Alleghanian orogeny with strain localization along the Monroe Fault. RCSM temperatures are shown. P-T diagrams are for (A) southern Quebec and (B) northern Vermont. The local P-T conditions are indicated by color patterns in each diagram. Additional P-T data used in these diagrams are from Spear et al. (2002) and Menard and Spear. (1994) for central Vermont, and from Armstrong et al. (1992) and reference therein for southern Vermont and Connecticut.

This article is protected by copyright. All rights reserved 


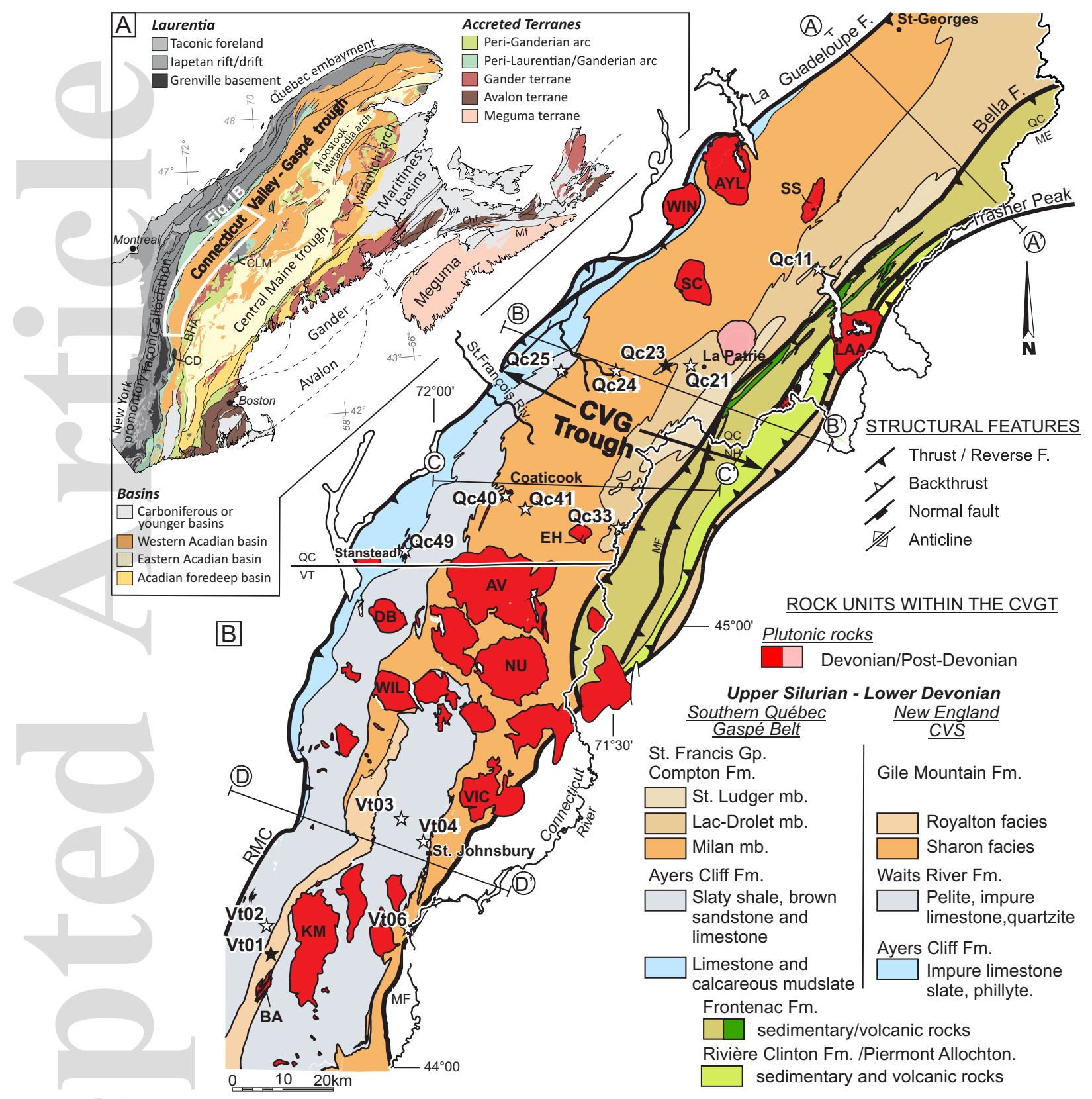




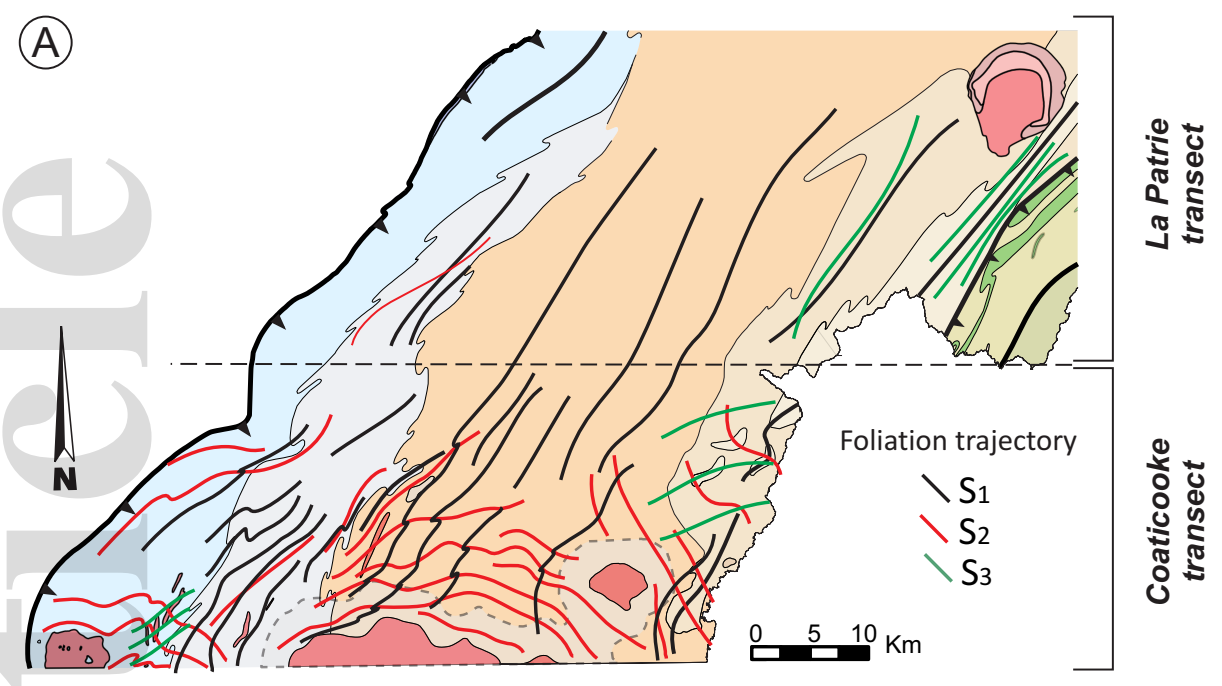

(B)
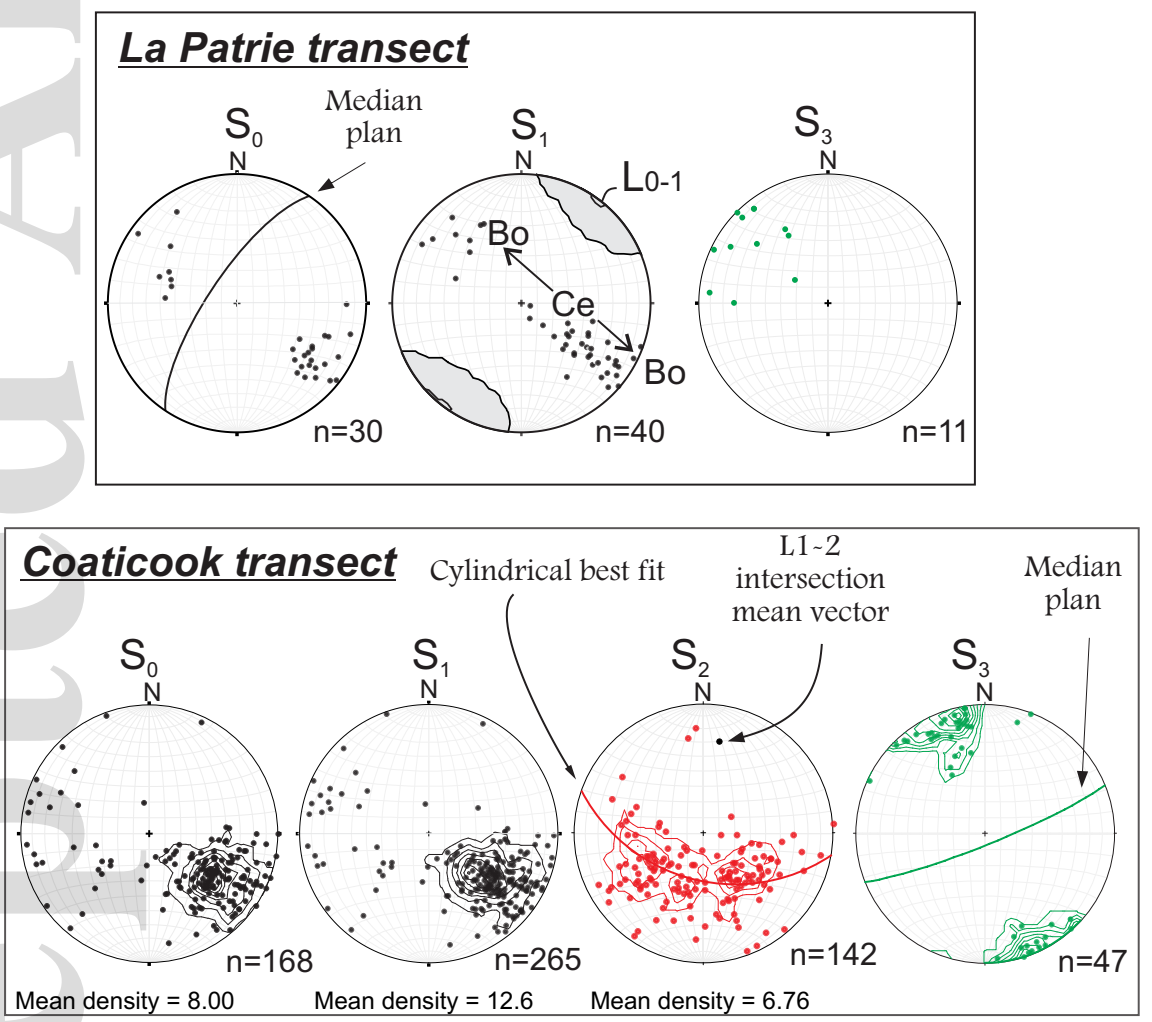


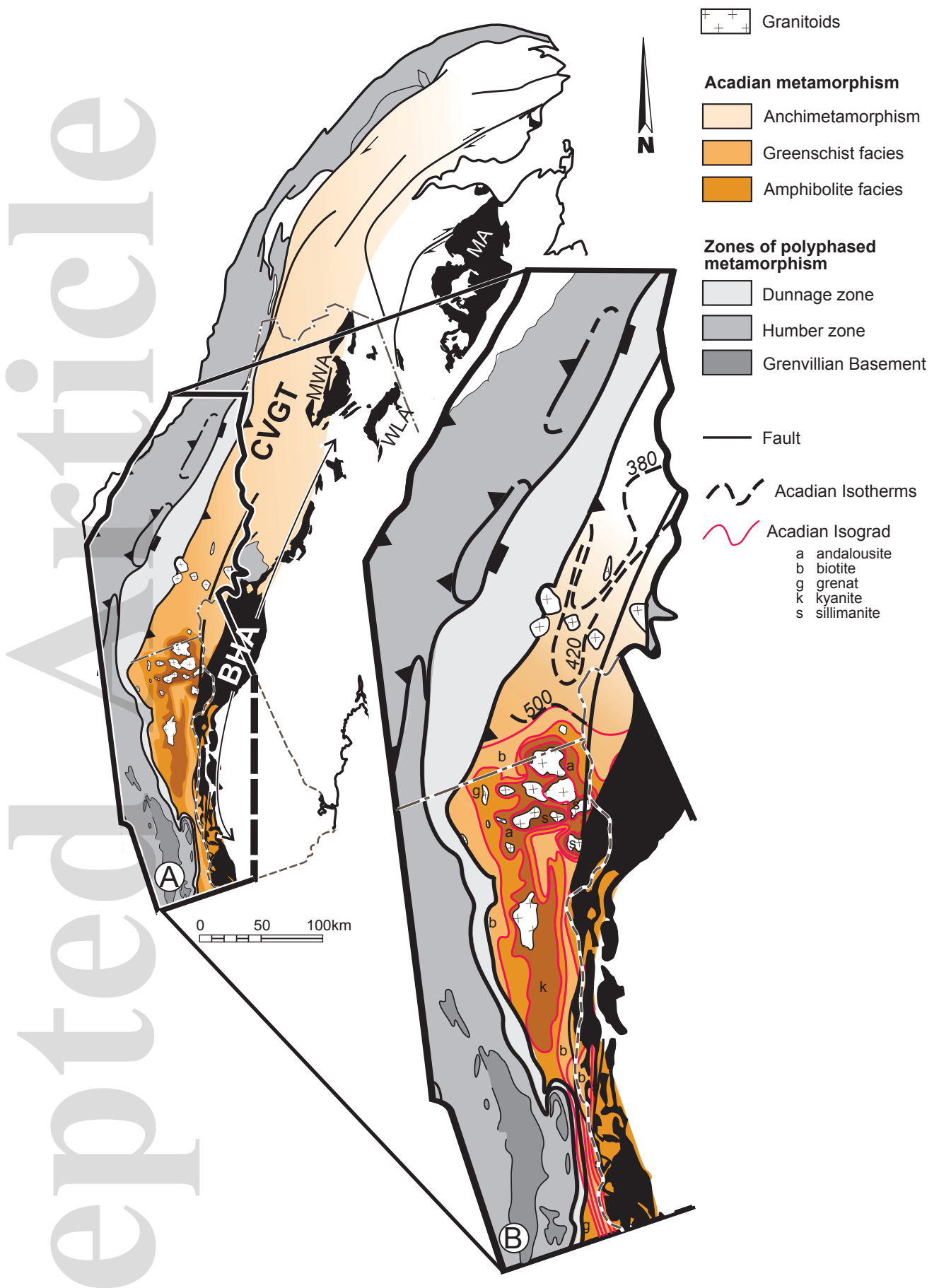



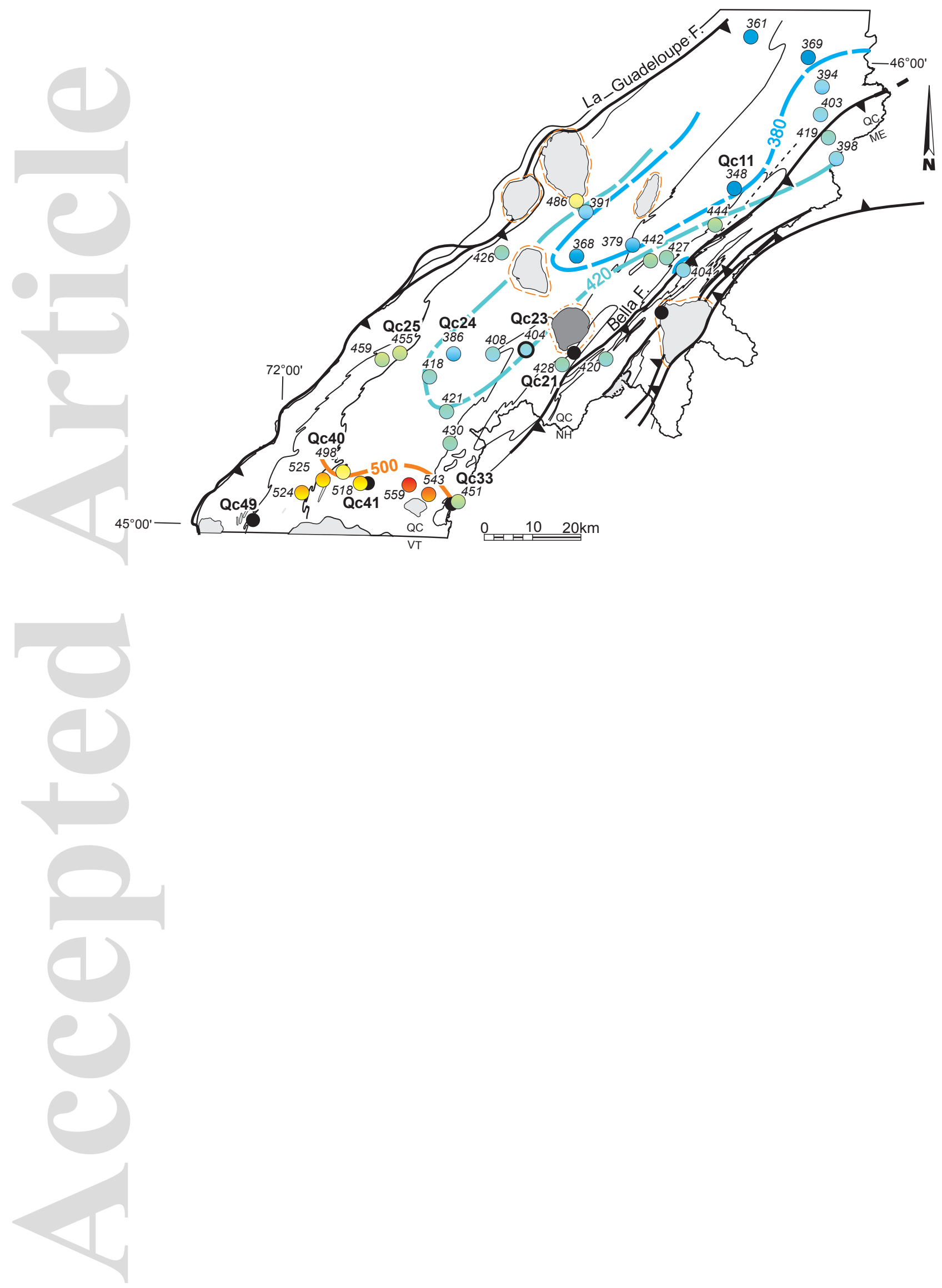


\section{Qc23}

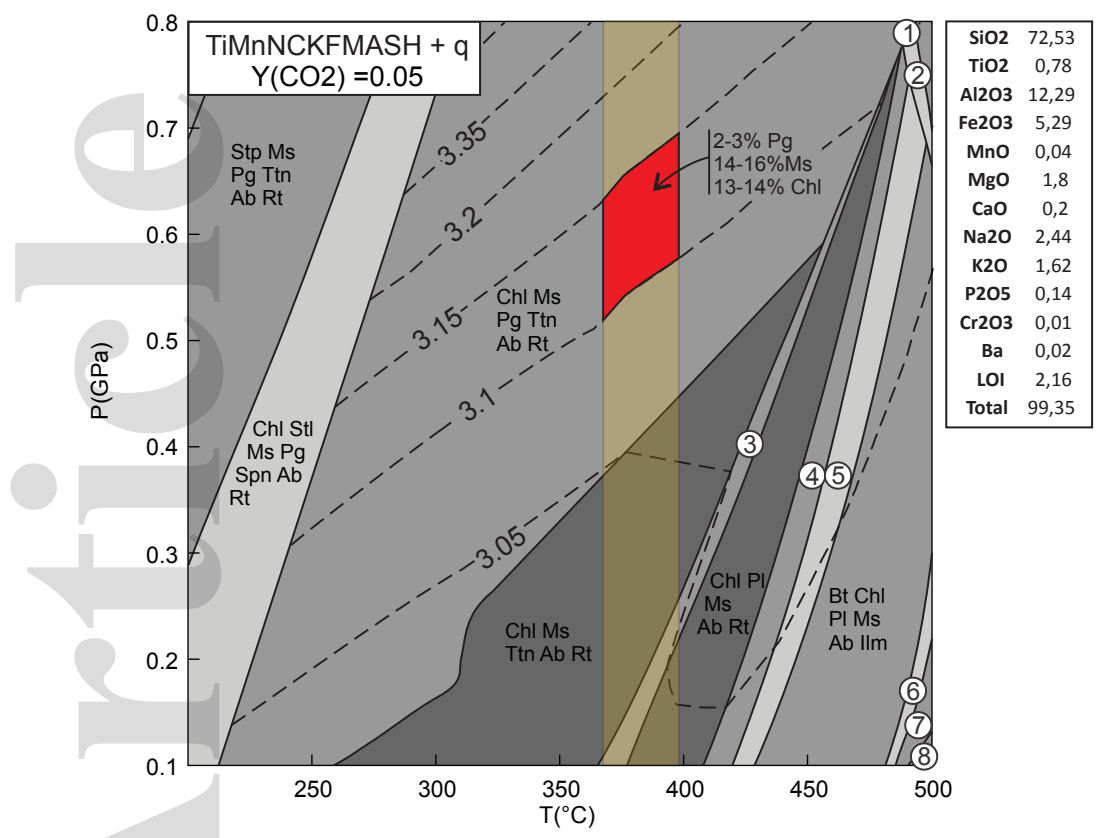
1. Bt Chl Ms Pg Spn Ab Rt
5. Bt ChI PI Ms Ab Rt IIm
2. Chl PI Ms Pg Ab Rt
6. Bt Chl PI Ms Pg Ab IIm
3. ChI PI Ms Spn Ab Rt
7. Bt Chl Crd PI Ms ab IIm
4. Bt Chl PI Ms Ab Rt
8. Bt Crd PI Ms Ab IIm 
A

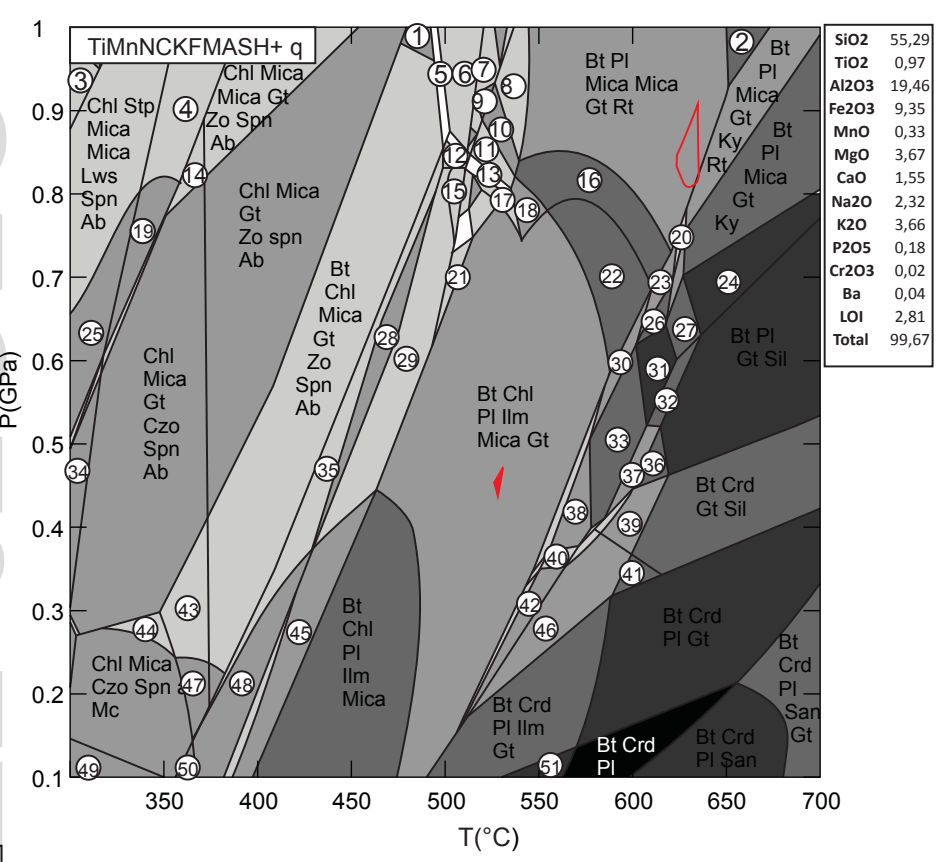

\section{Vt01}

$\begin{array}{ll}\text { 1. Bt Chl Mica Gt Spn Ab } & \text { 26. Bt St Pl Mica G } \\ \text { 2. Bt Gt Ky }\end{array}$

3. Stp Mica Mica Law Spn GIn Ab

28. Bt Chl PI Mica Gt Spn

4. Chl Mica Mica Gt Lws Spn Ab 29. Bt Chl Pl Ilm Mica Gt Spn

5. Bt Chl Mica Mica Gt Zo Spn Ab 30. Bt St Pl llm Mica Gt

6. Bt Chl Mica Mica Gt Zo Spn 31. Bt St PI Gt

7. Bt Mica Mica Gt Zo Spn Rt 32 . Bt St PI Gt Sil

8. BtPI Mica

9. Bt Mica Gt Zo Spn Rt

10. Bt PI Mica Gt Zo Rt

11. Bt Chl PI Mica Gt Zo Rt

12. Bt Chl PI Mica Mica Gt Spn

34. Chl Stlp Mica cz Spn ab

35.

13. Bt Chl PI Mica Mica Gt Zo Rt

14. Chl Mica Mica Gt Czo Spn Ab

15. Bt Chl Pl Mica Gt Spn Rt

36. Bt PI IIm Gt Sil

$m$ Gt S

38. Bt Chl St PI llm Gt

39. Bt Crd PI IIm Gt Sil

40. Bt Chl St PI llm Gt And

41. Bt Crd PI Gt And

16. Bt PI Mica Gt Rt

42. Bt Chl PI IIm Gt And

17. Bt Chl PI Mica Mica Gt Rt

43. Bt Chl Mica Gt Czo Spn ab

18. Bt Chl PI Mica Gt Rt

19. Chl Mica Gt Law Spn Ab

44. Chl Mica Gt Czo Spn ab Mc

20. Bt St PI Mica Gt Ky Rt 45. Bt Chl PI Ilm Mica Spn

21. Bt Chl PI Ilm Mica Gt zo 46. Bt Crd PI Ilm Gt And

22. Bt PI IIm Mica Gt 47. Bt Chl Mica Czo Spn ab

24. Bt PI Gt Ky

48. B Chl PI Mica Spn ab

49. Chl Mica spn ab Mc Wrk
50. Chl PI Mica Spn ab Mc

25. Chl Stp Mica Law Spn ab

51. Bt Crd PI IIm

B
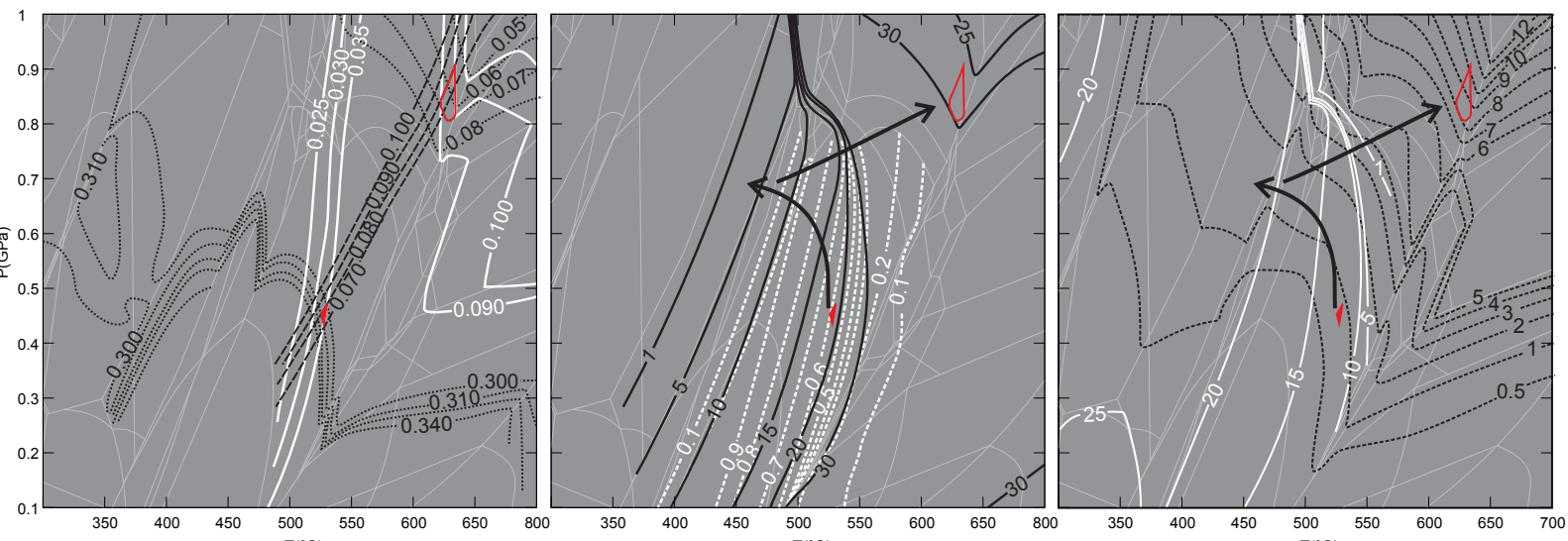

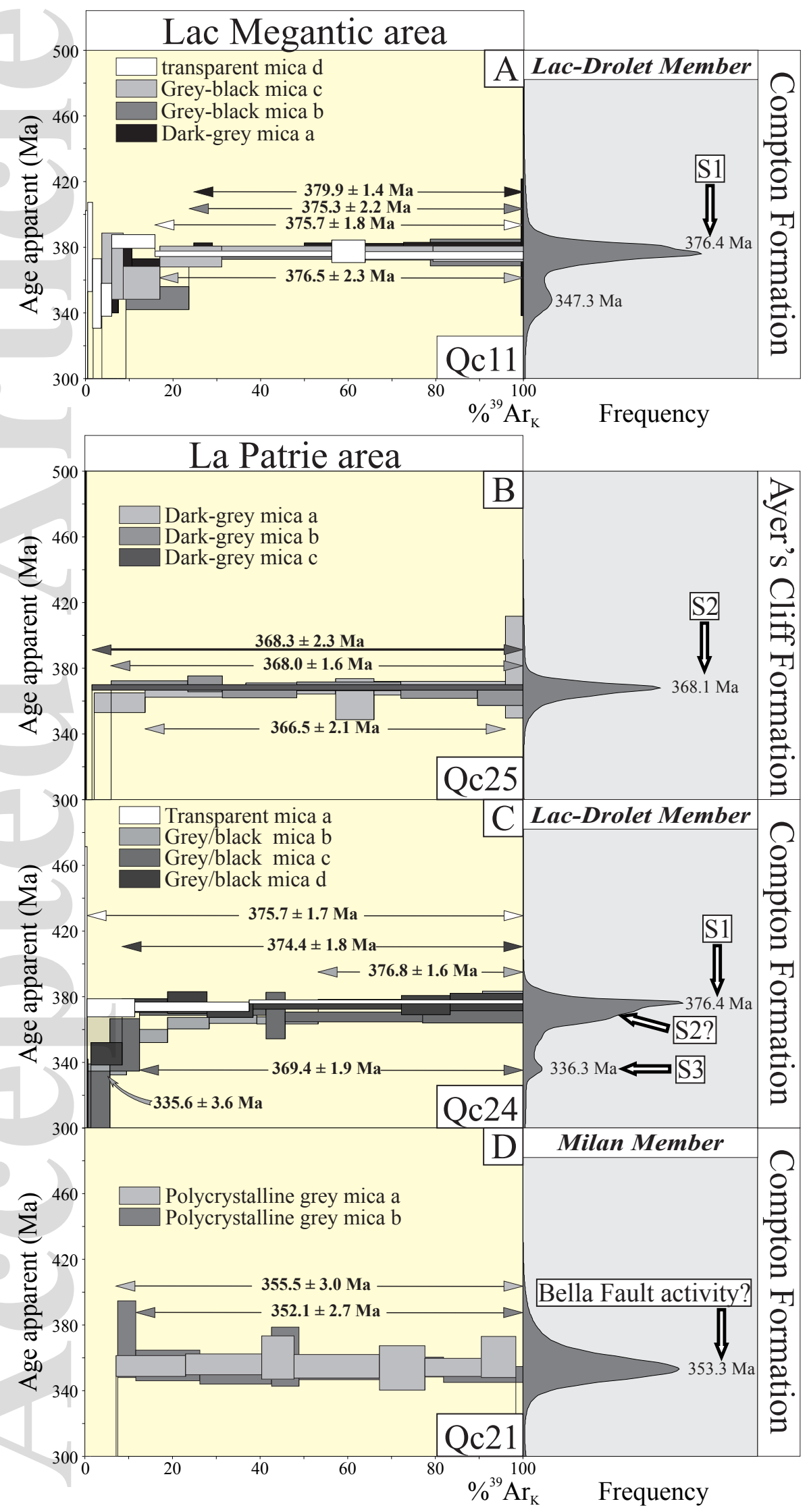


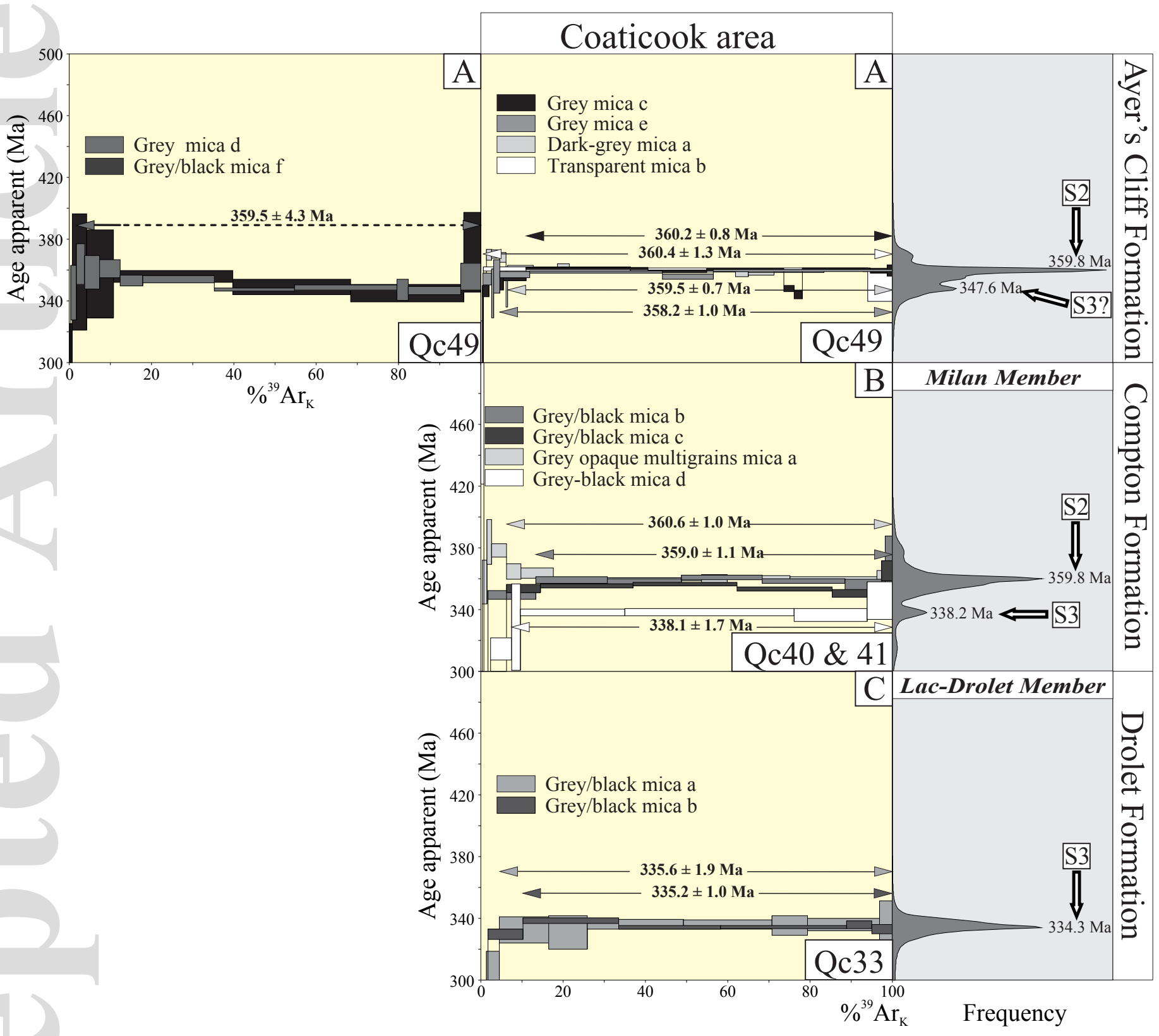




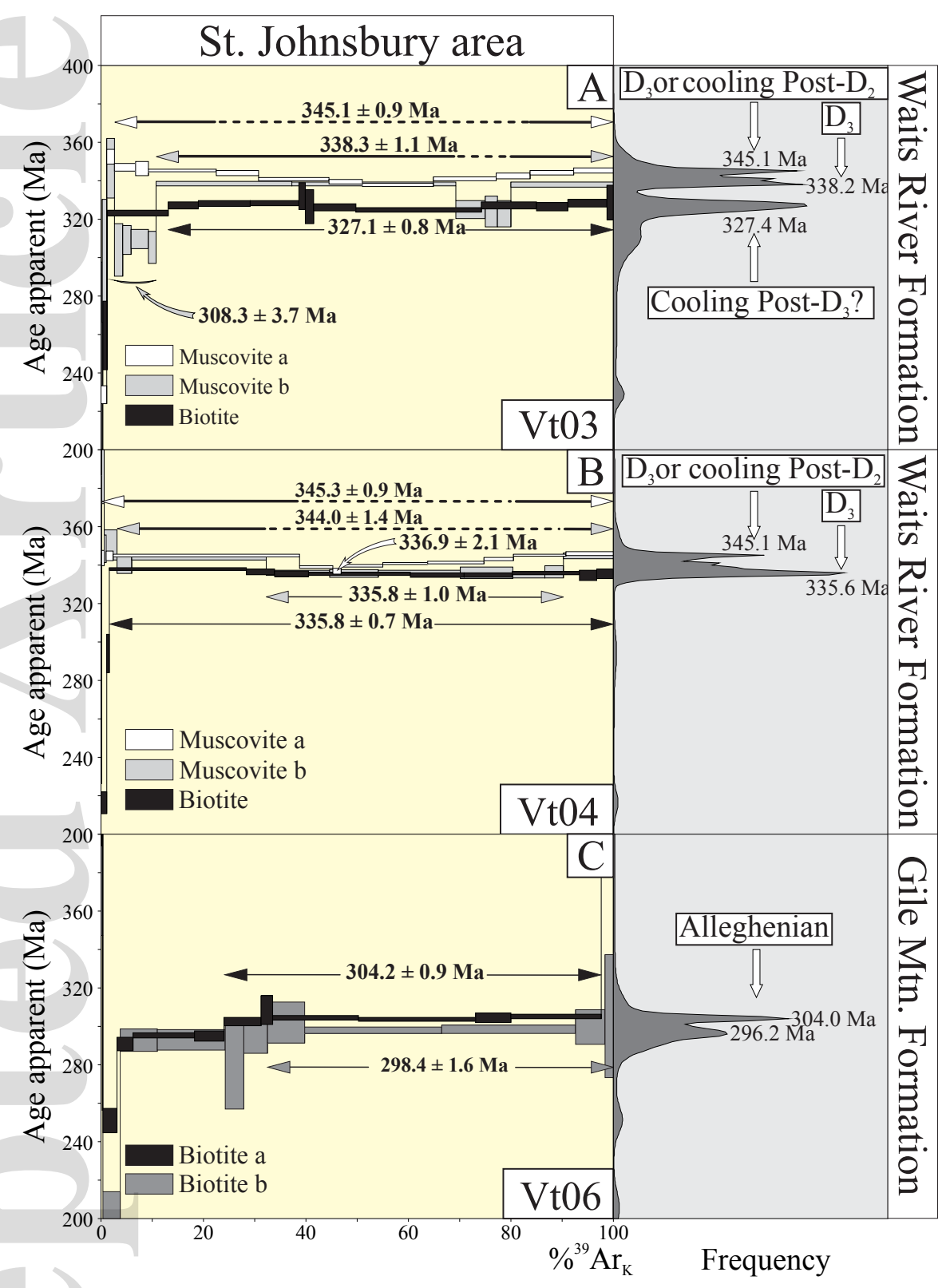

This article is protected by copyright. All rights reserved 


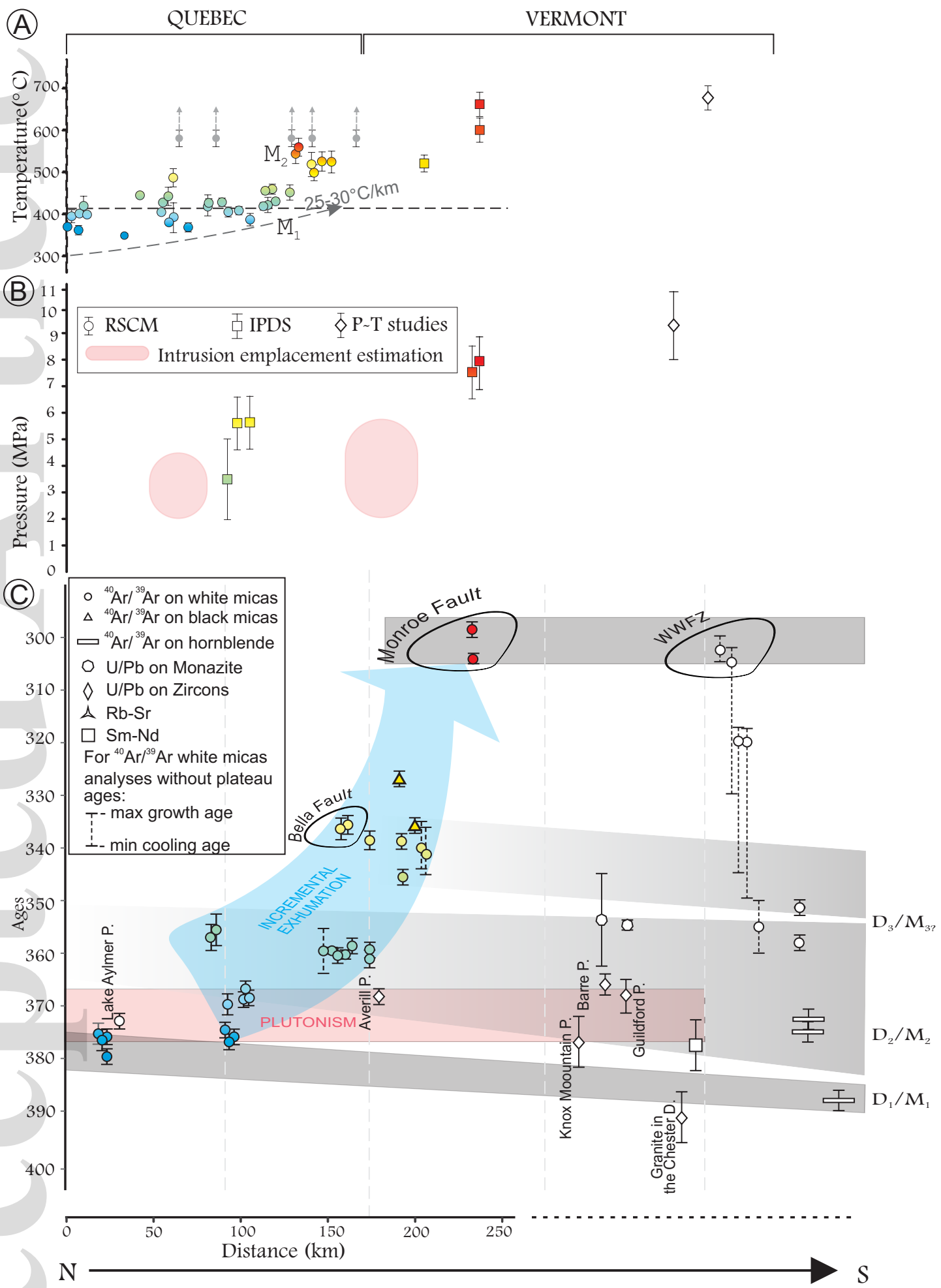




\section{0-300 Ma}
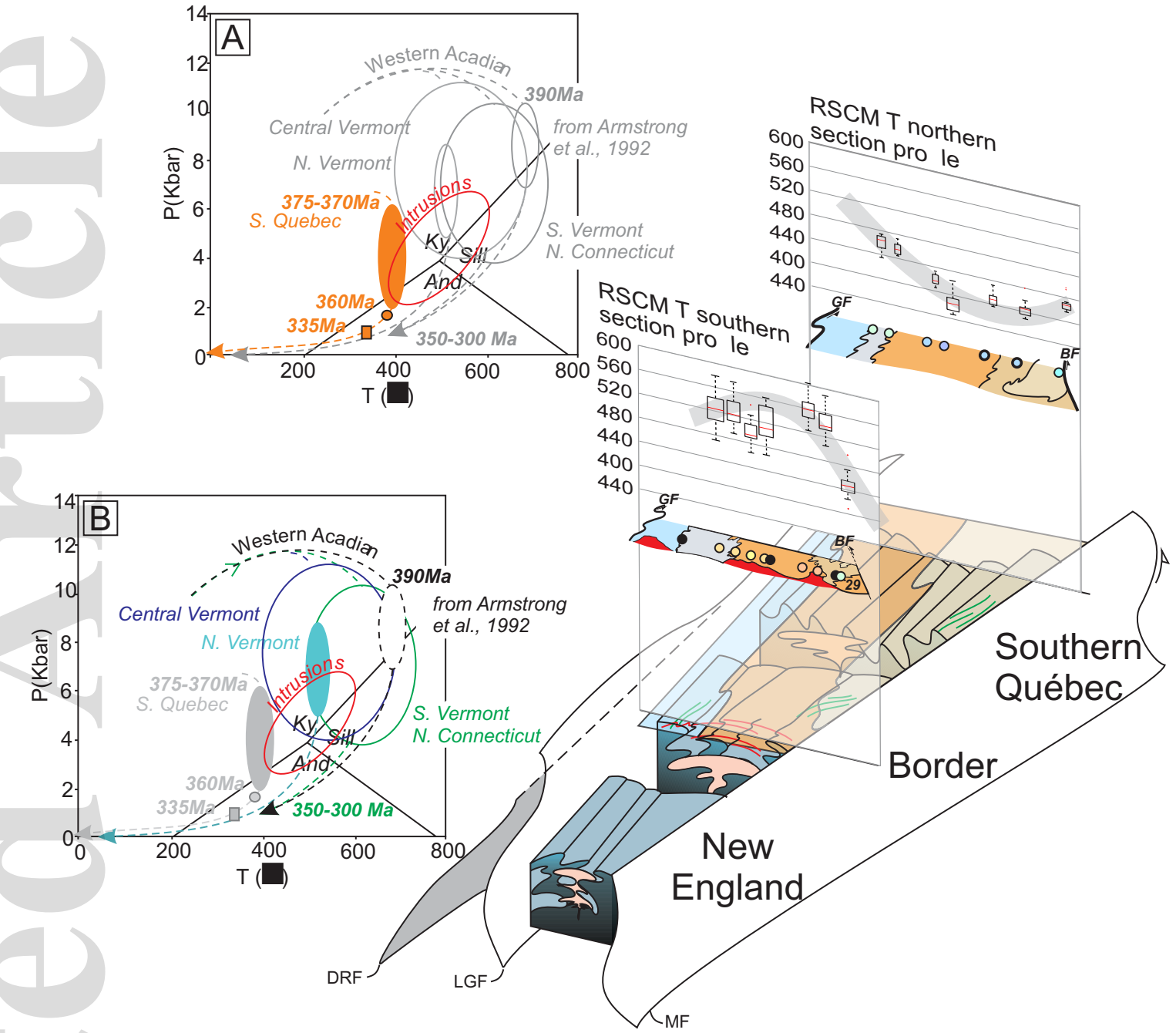

Fig. 15 Perrot et al.

This article is protected by copyright. All rights reserved 